CENTRE for ECONOMIC

$P$ E R F O R M A N C E

CEP Discussion Paper No 1650

September 2019

\title{
Understanding Day Care Enrolment Gaps
}

\author{
Jonas Jessen \\ Sophia Schmitz \\ Sevrin Waights
}




\begin{abstract}
We document day care enrolment gaps by family background in a country with a universal day care system (Germany). Research demonstrates that children of less educated or foreign-born parents can benefit the most from day care, making it important to understand why such enrolment gaps exist. Using a unique data set that records both stated demand and actual usage of day care we demonstrate that differences in demand cannot fully explain the enrolment gaps. Investigating supply-side factors using quasi-experimental designs, we find that reducing both parental fees and scarcity of places significantly decreases enrolment gaps by parental education but not by parental country of birth. We discuss implications for policy.
\end{abstract}

Key words: child care, early education, inequality, socio- economic status, discrimination, synthetic control

JEL Codes: I24; J13

This paper was produced as part of the Centre's Education \& Skills Programme. The Centre for Economic Performance is financed by the Economic and Social Research Council.

We are grateful to Mette Gørtz, Sandra McNally, Frauke Peter and C. Katharina Spiess, as well as seminar participants at the DIW Berlin for helpful comments. We also thank Benjamin Gedon for assisting us with the data. This research was conducted as part of a Marie Sklodowska-Curie action fellowship funded by the European commission (Grant number: 752053).

Jonas Jessen, DIW Berlin and Free University Berlin. Sophia Schmitz, DIW Berlin and Free University Berlin. Sevrin Waights, DIW Berlin and Centre for Economic Performance, London School of Economics.

Published by

Centre for Economic Performance

London School of Economics and Political Science

Houghton Street

London WC2A 2AE

All rights reserved. No part of this publication may be reproduced, stored in a retrieval system or transmitted in any form or by any means without the prior permission in writing of the publisher nor be issued to the public or circulated in any form other than that in which it is published.

Requests for permission to reproduce any article or part of the Working Paper should be sent to the editor at the above address.

(c) J. Jessen, S. Schmitz and S. Waights, submitted 2019. 


\section{Introduction}

By school starting age, children of less-educated or foreign-born parents are often behind their peers on measures of child development (e.g. Bradbury et al., 2015; Carneiro and Heckman, 2003). In many cases, these inequalities are already so deeply ingrained that they are difficult to address through the school system. Day care is considered an effective means of influencing child development in pre-school years, especially for children of lesseducated or foreign-born parents. ${ }^{1}$ As a result, universal day care is increasingly seen as an opportunity to "level the playing field" for children of different family backgrounds (e.g. Cornelissen et al., 2018; Felfe and Lalive, 2018; Havnes and Mogstad, 2011, 2015).

As a political concept, universal day care aims to ensure that all households, regardless of their income or employment, have access to appropriate day care options. The role of parental fees, if in place at all, is to capture some of the consumer surplus to help fund the programme, but not to regulate supply and demand. As such, setting the right level of fees and meeting resultant demand for day care slots is largely the responsibility of the public sector. However, despite expanding access to day care, there remain enrolment gaps across many OECD countries, even where universal day care systems are in place (e.g. OECD, 2018).

One reason that enrolment gaps may exist under a universal system is if less-educated or foreign-born parents simply have a lower demand for day care. This could be the case if they tend to prefer informal care arrangements, have more critical attitudes toward day care, expect lower returns to investment in their children, or expect lower returns to working (Boneva and Rauh, 2018; Cunha et al., 2013). Another reason that enrolment gaps may exist is if there are shortages of day care slots or inhibiting day care fees. Less-educated or foreignborn parents may be more affected by shortages if, for example, being better-resourced

\footnotetext{
${ }^{1}$ Payoffs exist in general because many skills develop early in life (e.g. Phillips et al., 2000) and because longer payoff periods make early learning more productive (Becker, 1975). There may also be important "dynamic complementarities" since early inputs strongly affect the productivity of later inputs (e.g. Cunha and Heckman, 2007).
} 
helps parents secure scarce slots, or if discrimination is exacerbated under shortages. ${ }^{2}$ Less- $^{-}$ educated or foreign-born parents may also be less able to afford day care fees, even where parental contributions are income-adjusted.

In the spirit of universal day care, we think of 'demand' in this paper as a simple yes/no dichotomous measure that captures parental preferences for using day care, i.e. whether they would enrol their child if offered a slot of appropriate quality at a non-inhibitive cost. ${ }^{3}$ We think of 'supply' factors as any barriers to access that might prevent parents from enrolling, such as a lack of availability or affordability (i.e. high parental contributions), or even a lack of appropriate quality of places.

In order to investigate demand- and supply-side causes of day care enrolment gaps, we use a large representative survey data set of more than 62,000 children younger than three in Germany. Using this data, we start out documenting gaps in day care enrolment by parental education and parental country of birth. ${ }^{4}$ We then explore the demand side as an explanation for observed gaps by making use of the fact that our data set reports stated demand for day care irrespective of actual enrolment. To examine the role of scarcity of places, we create a measure of local shortages that is the difference between demand and the number of slots at the county level. We estimate the effect of shortages on the enrolment gap in a panel fixed effects model. As such we make use of within-county changes in shortages over time that largely reflect differences in the timing of the roll-out of places across Germany. Finally, to examine the role of parental fees, we use the synthetic control method to estimate the impact of a substantial reduction of fees due to a policy change in one German federal state.

We find enrolment gaps of 14 percentage points by parental education and 12 percentage points by parental country of birth - corresponding to gaps of around 37 percent in each

\footnotetext{
${ }^{2}$ In a randomised controlled trial, Andersen and Guul (2019) show that discrimination by public school teachers is most acute when workloads are high.

${ }^{3} \mathrm{~A}$ willingness-to-pay measure would be problematic in that it captures ability to pay, or household income, rather than only strength of preference. Enrolment gaps due to low-income households having a smaller willingness-to-pay than the subsidised fees are framed as an access barrier rather than a demand-side problem.

${ }^{4}$ These factors are more fixed than income or employment, which are endogenous with day care enrolment.
} 
case. We show that the demand gaps for these family backgrounds are much smaller than the enrolment gaps. In fact, for children with migrant family backgrounds there is hardly any demand gap at all. Overall, the enrolment gaps cannot be fully explained by differences in demand. On the supply-side, we find that reducing day care shortages significantly decreases the enrolment gap by parental education but has no effect on the migrant-native gap. Similarly for parental fees, a large reduction in one state significantly reduced the enrolment gap by parental education but had no impact on the gap by parental country of birth.

In terms of policy implications, the results suggest that the enrolment gap for lesseducated parents may be reduced by reducing fees and/or through increasing availability. However, the enrolment gap by parental country of birth does not seem to be affected by changes to these supply constraints. Our results imply that the gap for foreign-born parents reflect barriers to access that remain even when day care is available and affordable. We suggest two possibilities: (i) that foreign-born parents face discrimination even where shortages of places is less acute, or (ii) that foreign-born parents do not find the quality of care to be adequate. The latter possibility could be the case if the quality of care is lower in the areas where foreign-born parents typically live, if foreign-born parents are more greatly affected by quality issues that affect everyone such as group size, or if foreign-born parents are affected by specific quality concerns such as a lack of multilingual teachers or consideration of different cultures.

This paper is closely related to the literature on the evolution and causes of educational inequalities and intergenerational educational mobility (see e.g. Björklund and Salvanes, 2011, for an overview). The existing economic literature mainly focuses on exploring socioeconomic status gradients in educational attainment or achievement, with a particular focus on higher education (e.g. Boneva and Rauh, 2017; Machin and Vignoles, 2004; Hanushek et al., 2019). Such gaps are both well documented and well understood in terms of their major determining factors. Conversely, gaps in early educational settings are less well understood, despite the crucial importance of this early phase of life for later outcomes. Large 
and persistent gaps in enrolment in early education and care are well documented across different institutional settings (e.g. Greenberg, 2011; Magnuson and Waldfogel, 2016; Stahl and Schober, 2018; Zachrisson et al., 2013). However, the literature on the underlying drivers of such gaps is thin. In particular, it lacks good data capturing demand- and supply-side factors, thus failing to answer convincingly why day care enrolment gaps exist. Most previous research on the different demand- and supply-side factors is purely descriptive and based on cross-country variation (e.g. Pavolini and Van Lancker, 2018) or time variation within a single country or region (e.g. Sibley et al., 2015). ${ }^{5}$ The evidence from these studies is mixed. There is some suggestive evidence that supply-side factors, for example, the availability of day care or its fees, are important for explaining the large gaps in day care enrolment (e.g. Abrassart and Bonoli, 2015; Bainbridge et al., 2005; Sibley et al., 2015; Pavolini and Van Lancker, 2018). Others find the fee structure and the level of provision to be less important (Van Lancker, 2018; Van Lancker and Ghysels, 2012).

We address this gap in the literature by using a large and representative data set of children below the age of three in Germany that allows us to not only observe actual day care enrolment but also demand for day care. Thus, we can provide evidence on whether gaps in enrolment in early education and care simply reflect differences in demand between groups. In addition, we use different empirical methods to investigate the role of regional availability of day care spots and fees in explaining gaps by family background. The paper proceeds as follows: Section 2 outlines the institutional background, Section 3 describes the data used. Section 4 documents enrolment gaps by family background and examines the role of differences in demand. Section 5 presents the impact on enrolment gaps for (i) local day care shortages and (ii) day care fees. Section 6 interprets the results and provides policy implications. Section 7 concludes.

\footnotetext{
${ }^{5}$ In addition, many previous studies define low-socioeconomic status by household income, a problematic approach since the labour supply decision of women on the intensive and extensive margin is likely to be endogenous to day care enrolment.
} 


\section{Institutional background}

In recent years, there has been a strong political effort to increase the provision of universal and publicly subsidised day care in Germany. Thanks in part to a legal claim for children older than three, in place since 1996, enrolment rates have consistently been above 90 percent in the 2010s for this age group. For under threes, enrolment rates were persistently low until around 2005. In 2005 (TAG) and in 2008 (KiföG), two laws came into effect at the federal level, committing local governments to gradually expand day care places for children under the age of three. From August 2013 onward, every child above the age of one has a legal claim to a place in day care. The reforms lead to a large increase in enrolment rates of children under three. Whereas in 2006 the fraction of children under the age of three enrolled day care was about 12 percent, the enrolment rates in 2018 were just under 34 percent. Despite this increase, there are large and persistent day care shortages; i.e. demand for day care far exceeds the number of places (Alt et al., 2017). In addition, the expansion has happened heterogeneously across states, counties and municipalities, resulting in large variation in day care shortages across regions.

The German day care system is highly decentralised with three levels of government (federal, state and municipality), youth welfare offices (which mostly cover areas identical to counties) as well as providers sharing responsibilities (Spieß, 2008). While the federal government sets out the broad framework, the funding lies under the responsibility of the states and municipalities. Municipalities must also decide through forecasts how many slots need to be provided, but the provision itself is often done by non-profit providers. Non-profit providers must be licensed by the youth welfare offices as being part of the local provision plan and to ensure that the states' required standards for services are being met. Almost all day care places are publicly subsidised and provided by the municipalities themselves or by non-profit organisations, including churches and welfare associations. For example in 2017, $33 \%$ of day care institutions were public providers, $59.2 \%$ other non-profit organisations, and

only $2.6 \%$ of institutions were private and non-charitable (Statistisches Bundesamt, 2017). 
On average, public subsidies cover about $70 \%$ of day care costs (Spieß, 2013), with some states covering $100 \%$ for certain age groups and households.

The remaining proportion of day care costs is partly covered by parental fees. The fees parents pay are usually income-dependent with a progressive fee structure. ${ }^{6}$ In some states and municipalities, it also depends on other factors, such as the number of siblings, hours of day care, and type of provision. There is no uniform rule at which regional administrative unit the level of fees and exemption of fees are determined; as of 2018, in only one out of the 16 federal states (the city-state Hamburg) this is determined centrally at the state level, in four states at the level of youth offices, in three at the municipality level, in five states at the carrier level and in three states at the municipality and carrier level (Autorengruppe Bildungsberichterstattung, 2018). Some low-income parents, particularly all welfare recipient families, ${ }^{7}$ are exempted from paying fees. Overall, parental fees amount to about 5-10\% of average earnings. Thus, they are lower than the OECD average and much lower than in countries with low public subsidies like the US (OECD, 2016, 2019) and, importantly, fees are fixed for certain periods of time and not determined by changes in demand or supply. However, fees vary widely across regions, income, and family structure (Schmitz et al., 2017).

Before the introduction of the legal claim to day care for all children above the age of one in August 2013, the federal law (KiföG) stipulated that children whose parents (or the single parent) are employed, in education, or receive unemployment benefits (Leistungen zu Eingliederung in Arbeit im Sinne des Zweiten Buches) must be granted access to day care. ${ }^{8}$ Ultimately, these regulations provided preferential access to households without a stay-athome parent. Since the prevalence of stay-at-home parents may vary by parental background, this change in law could potentially have impacted on enrolment gaps. However, we do not

\footnotetext{
${ }^{6}$ Parental fees are not paid to the individual day care institution. Thus, day care centres usually have no financial incentive to take in children from families with higher income. However, they get larger subsidies when they take in children with special needs.

${ }^{7}$ Children from welfare recipient families are in principle entitled to free day care. However, the law is not binding.

${ }^{8}$ Some states and municipalities had additional regulations. For example, they gave priority in access to single parent families or families who do not speak German at home (e.g. Spieß, 2008).
} 
believe this to be a confounding relationship for our analysis. ${ }^{9}$ Indeed our results are robust to using just the periods before the change or just the periods after the change. ${ }^{10}$

Generally, families can freely decide which day care institution they choose. However, due to severe day care shortages, the number of applications is typically much larger than the number of available spots. ${ }^{11}$ The allocation of scarce slots is largely uncoordinated (e.g. Fugger et al., 2017) and varies by region and the type of provider. Some providers and counties have transparent selection criteria and a centralised application system, many others do not. For example, public providers sometimes prioritise children who already have or had a sibling in the same facility or live close by. Day care provided by churches might in addition select families based on their religious affiliation (e.g. Herzog and Klein, 2018).

\section{Data}

In our empirical analysis, we use a unique representative data set, the German Child Care Study $(K i B S)$ of the German Youth Institute (DJI). The KiBS is an annual survey of children and their households with a specific focus on children's care arrangements (Alt et al., 2018). The survey was first conducted in 2012 and we use information from all available waves, covering 2012 through 2016. In each wave, the KiBS surveys approximately 800 children in each of the 16 federal states in Germany. The data also include appropriate weights for conducting national-level analyses. ${ }^{12}$ We focus on children in the under three age group, where there is still considerable variation in day care enrolment. In total, we observe 62,437 children below the age of three, making the data set the largest available to analyse day care

\footnotetext{
${ }^{9}$ Our analysis is conducted at the local level, whereas the change in law was a national policy shift. We have no reason to believe that the effects on the enrolment gaps were differential at the local level nor correlated with change in shortages.

${ }^{10}$ Available on request.

${ }^{11}$ Despite the legal entitlement for all children above the age of one, there are few cases of legal action. According to KiBS data, less than $1 \%$ of parents who state having demanded a slot but not receiving one, report having undertaken legal action already.

${ }^{12}$ The sampling design leads to smaller states being oversampled. Survey weights, calculated on the state level, account for this. A comparison of the weighted share of children under the age of three in day care with administrative statistics in Appendix Table A1 shows that they resemble each other closely. All figures and tables in this paper are based on weighted calculations using the KiBS data unless indicated otherwise.
} 
enrolment in Germany.

\subsection{Day care demand and supply}

A unique feature of the data is that parents report demand for day care irrespective of actual enrolment. Parents are asked separately for each weekday, Monday-Friday, whether they have a wish for day care on that day. If the parents report a wish for day care on any day then they are coded as having a day care demand. To ensure this represents an actual demand we create a stricter alternative measure that is equal to one only if the parent additionally reports having made at least one application for a day care slot. However, only around $5 \%$ of parents that report a wish for day care have not submitted any application, indicating that the measure already captures a real demand for day care.

Given pervasive shortages in the German context, we use actual enrolment as a measure of available day care slots. ${ }^{13}$ In any county, or for any child age group, we subtract the share of parents who have a slot from the share of parents who demand a slot to create a measure of shortages. Figure 1 plots day care demand, slots, and shortages (the difference) aggregated by the child's age in months. Below the age of one, both demand and slots are very low, but demand jumps when the child turns one. ${ }^{14}$ The number of slots exhibits a much smaller jump, which results in a substantial increase in shortages at this age. Afterwards, both quantity demanded and the number of slots increase continuously with a slightly steeper slope in availability. Overall, in our sample, $31 \%$ of children below three years are in day care. The fraction of parents stating a demand for a place in day care amounts to about $44 \%$. This implies that only $71 \%$ of demand is met, thus describing a situation of severe day care shortages.

In our analysis, we consider county-level shortages as one main explanatory variable

\footnotetext{
${ }^{13}$ Official day care statistics in Germany take the same approach, based on the (reasonable) assumption that the number of untaken slots is negligible.

${ }^{14}$ The sudden jump in demand between the 11 th and 12 th months is likely due to the end of paid parental leave (e.g. Kluve and Schmitz, 2018) and the start of the legal claim to day care (introduced in 2013).
} 
Figure 1: Day care enrolment, demand and shortage by age

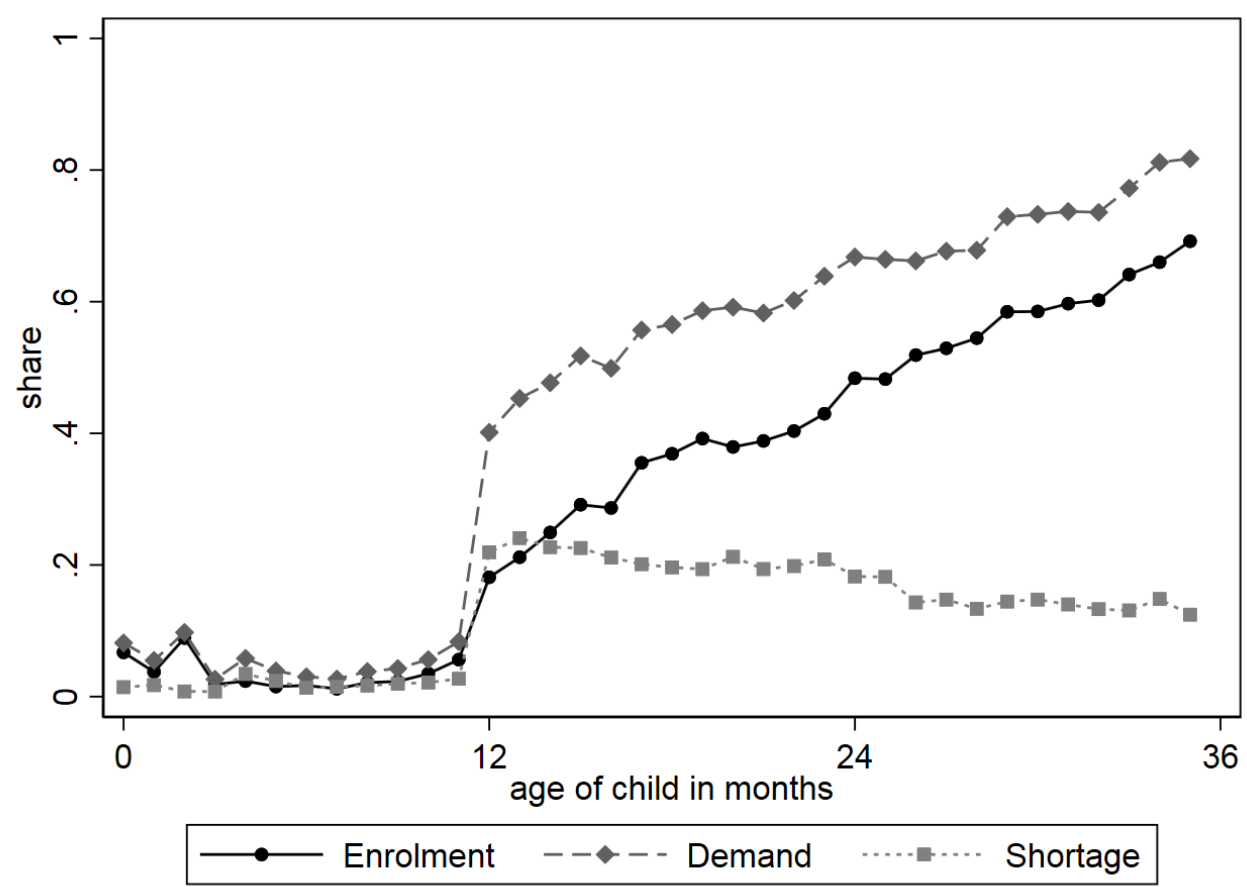

for the existence of enrolment gaps. ${ }^{15}$ County-specific day care shortages are defined as the fraction of parents who state that they have demand for a slot in day care but whose children are not enrolled in day care. County shortages range from 0 to $39.2 \%$. See Figure A1 for the distribution of county-level shortages and the deviations from state averages - the effective variation used in one of our specifications.

For our analysis of shortages, we make use of two types of variation: (i) across counties within states, and (ii) within counties over time. Since we aggregate individual data points to create county measures, we restrict the sample to have a minimum of 50 observations per county and year to reduce measurement error. This reduces the sample size from 62,473 to

\footnotetext{
${ }^{15}$ The publicly available data set only contains identifiers for the federal states. Through confidential onsite access we were granted access to anonymised county identifiers, i.e. we can distinguish between counties but not identify them unambiguously. We were also able to add some specific county-level controls in the analysis: an indicator for urban counties and indicators for the GDP tercile of counties within the state. As described in Section 2, many decisions regarding the provision of day care are enacted at the municipality level, one level smaller than counties, so an analysis at that level would in principle be appealing. However, municipality identifiers are not available and due to the granularity (10,848 municipalities exist in Germany) we would also be unable to create measures of local shortages. An analysis at the relatively fine county level is still an advancement on previous studies and, as can be seen in Figure A1, sufficient variation exists at that level.
} 
43, 691 (and the number of counties from 252 to 95), which has implications for the external validity of our results that we explore in Appendix Table A2. In short, our results are a little more relevant for larger, wealthier, and more urban counties. While our restricted sample is no longer perfectly representative of Germany, it remains a significant advancement on previous studies that focus on individual regions or highly selective groups. Furthermore, the results are robust to the removal of this sample restriction.

The data also contains information on day care fees, as reported by parents in one of the study years (2015). As described in the institutional context, fees vary by household income and other characteristics. For those enrolled in day care, average fees are just below 240 Euros a month. Note that this number is larger than hypothetical average monthly fees if all children were enrolled in day care, as fees are progressive and children from lower-income households are underrepresented in day care.

We also have information on a number of other demand-side factors, including the number of applications submitted to day care institutions and hours of day care demanded. Furthermore, the respondents are asked about reasons for not enrolling in day care. They are discussed in more detail in Sections 4 and 6.

\subsection{Family background}

The data set contains various socio-economic characteristics of the main respondent and the household. We focus on two main indicators to measure enrolment gaps: parental education and parental migration background. ${ }^{16}$ The less-educated parents indicator is equal to one for children where the respondent parent has no university entrance qualification (Abitur) and zero otherwise. ${ }^{17}$ The foreign-born parents indicator is defined as being equal to one

\footnotetext{
${ }^{16}$ Children from foreign-born parents have the same right to day care as children from native parents. Different rules apply for refugee children, but very few would be in the data in the sample period.

${ }^{17}$ Educational differences by Abitur vs. no-Abitur are reflected in financial resources of the household and tertiary education obtained, making it a variable that captures socio-economic status. Another common distinction made in the literature is whether parents have obtained tertiary education. As this information is not available in all waves, we do not use this measure in our main specification, but report results in the appendix.
} 
for children where both parents (or the single parent) are born in a non-Western European and non-North American country. ${ }^{18}$ We make this distinction since Western European and North American countries are in many ways similar to Germany. As a result immigrants from these countries should be affected by shortages and fees similarly to Germans. Overall $48 \%$ of children are defined as being from a less-educated household and 15\% are defined as having two foreign-born parents.

Our selection of these indicators is based on several factors. Firstly, these are the subgroups for which enrolment gaps are often documented in research and in the public debate. Secondly, these are the sub-groups most commonly found in the literature to have greater child development benefits from day care enrolment. Thirdly, these indicators are thought to be more fixed (exogenous) with respect to day care enrolment compared with alternatives such as household income or labour force participation. Fourthly, it is plausible that both of these groups face barriers to accessing public services, with each exploring a slightly different dimension. For example, the foreign-born group may be more exposed to discrimination, have a smaller network of German acquaintances, be less knowledgeable of the (application) system and have lower levels of German-language skills; things that may give an edge in securing a spot in a competitive environment. In the appendix, we investigate enrolment gaps by alternative indicators: no university degree (57\% of our sample), main language at home not German (16\%), ${ }^{19}$ welfare recipients (19\%) and below-median pre-birth income (the last two measures are only available in wave 4 , and waves 4 and 5, respectively).

Table 1 presents summary statistics of our sample. Observation numbers differ between the variables, as not all questions are asked in each wave and some are conditional on day care enrolment.

\footnotetext{
${ }^{18}$ There are no parents from Australia or New Zealand in our data.

${ }^{19} 10 \%$ of families speak German and another language to a same degree at home, meaning that only $6 \%$ predominantly speak another language.
} 
Table 1: Summary statistics

\begin{tabular}{lccccc}
\hline \hline \multicolumn{1}{c}{ Variable } & Obs & Mean & Std. Dev. & Min & Max \\
\hline Day care enrolment, demand and preferences & & & & & \\
Day care enrolment & 62473 & .31 & .463 & 0 & 1 \\
Day care demand & 62435 & .436 & .496 & 0 & 1 \\
Day care shortage & 62435 & .125 & .331 & 0 & 1 \\
Total monthly fees (in Euros) & 6149 & 238.363 & 137.622 & 0 & 730 \\
Hours of day care demanded & 57970 & 13.499 & 18.002 & 0 & 60 \\
Number of applications & 35710 & 2.417 & 3.718 & 0 & 25 \\
Day care demand - strict measure & 35994 & .413 & .492 & 0 & 1 \\
Family background & & & & & \\
Less-educated (no Abitur) & 62473 & .48 & .5 & 0 & 1 \\
No university degree & 49664 & .571 & .495 & 0 & 1 \\
German not main language at home & 62287 & .162 & .369 & 0 & 1 \\
One foreign-born parent & 62473 & .028 & .164 & 0 & 1 \\
Two foreign-born parents (\& non-Western) & 61338 & .151 & .358 & 0 & 1 \\
Welfare recipient & 23758 & .185 & .388 & 0 & 1 \\
Other household and child characteristics & & & & & \\
Age of child (months) & 62473 & 18.294 & 9.326 & 0 & 35 \\
Female child & 62473 & .483 & .5 & 0 & 1 \\
Number of children in household & 61993 & 1.812 & .859 & 1 & 5 \\
Respondent has a partner & 62271 & .969 & .173 & 0 & 1 \\
Married & 62473 & .789 & .408 & 0 & 1 \\
\hline \hline
\end{tabular}

Notes: Summary statistics pooled over all waves. The strict demand measure denotes an indicated demand for day care and further requires at least one application to have been submitted. Questions on general preferences for day care (not demand) asked in waves 1 to 4 . Questions on fees are only asked in wave 4 for those enrolled. Questions on pre-birth income only in wave 4, on number of applications in waves 3 to 5 , on welfare payments in wave 4 and 5 . Low education denotes that the respondent's highest school degree is not Abitur, which qualifies for university entrance. Monthly fees, number of applications, pre-birth income and number of children in household are winsorised at the 99th percentile. 


\section{Enrolment gaps by family background and the role of demand}

Figure 2 shows the gaps in enrolment and demand for our two main categories (less-educated and both parents born abroad) plus two alternative categories (no university degree and German not main language at home). The coefficients are obtained from regressing enrolment

and demand on the binary categories of family background. ${ }^{20}$ Children from less-educated parents have on average about 14 percentage points (ppt) lower enrolment rates than children from more-educated parents (about 37\% lower) but only about 8 ppt lower demand (17\% lower). Comparing the gaps in relative terms, demand would not seem to be able to explain much more than one half of the gap. Children with both parents born abroad also have a significant enrolment gap of about 12 ppt (37\% lower) but have almost no demand gap (2 ppt, or $5 \%$ lower). Thus, the demand-side does not seem to be a main explanation for the migrant-native gap. The gaps for our two alternative categories are quite consistent with our main categories.

To show that differences are not just driven by overlapping categories, we also produce the gaps by education and migration background when conditioning on (not) having a migration background and having high-(or less-) educated parents, respectively. Results are shown in Appendix Figure A3. The overall patterns remain, especially that demand does not seem to be a main explanation for enrolment gaps by migration background.

Table 2 provides potential explanations for the different levels of stated demand. It shows the reasons that parents give for not enrolling in day care. Focusing on the five demandside issues (indicated by a $D$ in parentheses), differences are overall more pronounced by education level. For example, less-educated parents are 15 ppt more likely to state 'I'm at home myself' as a reason for not using day care (whereas the difference is only 5 ppt for

\footnotetext{
${ }^{20}$ Appendix Figure A2 shows these gaps specifically by parents' country of origin, Appendix Table A3 compares the distribution of birth countries in our data with official statistics and characterises the sample by country of origin.
} 
Figure 2: Gaps in day care enrolment and demand

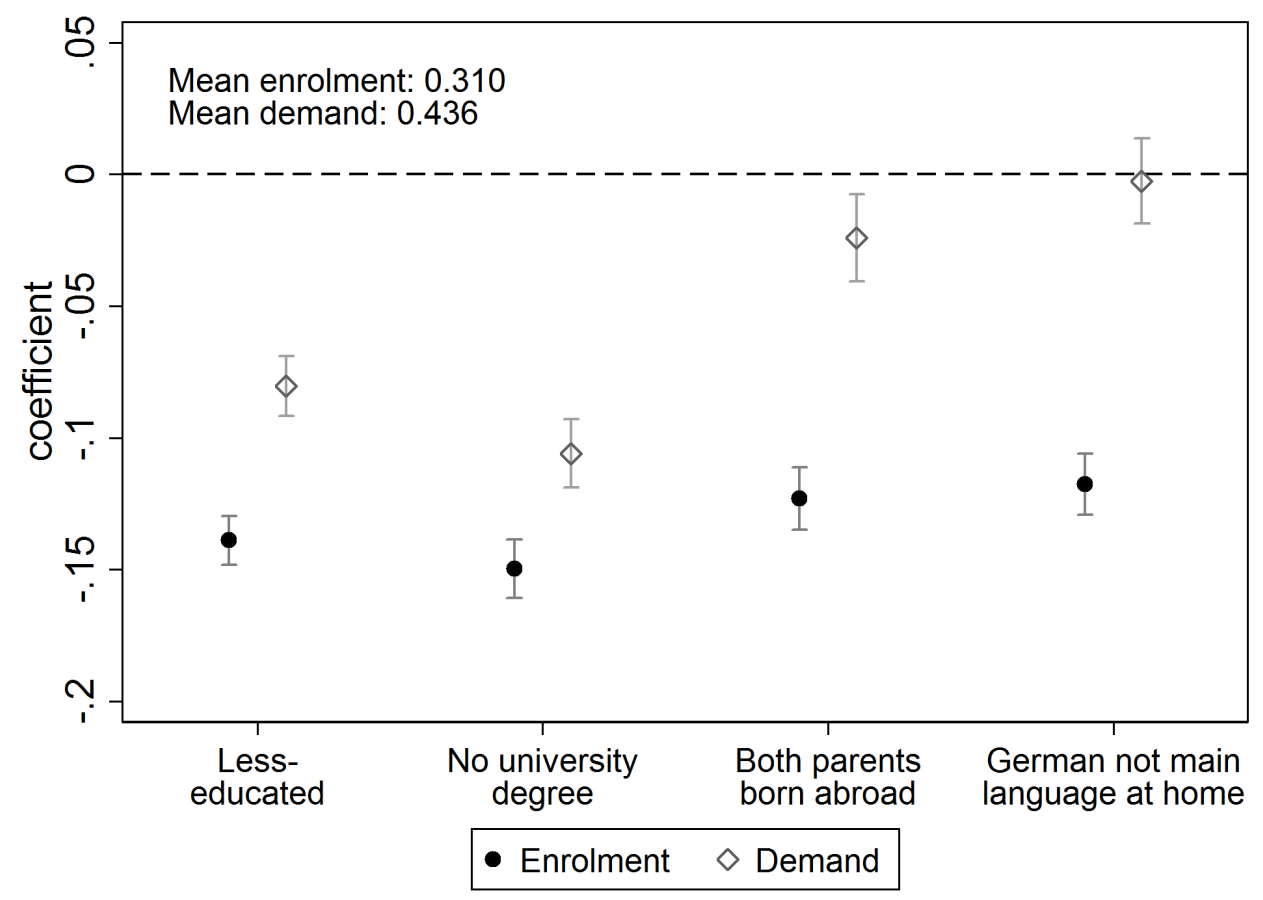

Notes: Figure shows differences in day care enrolment and demand by four measures of family background. Coefficients stem from regressing the dependent variable on the indicator for family background in separate regressions. The mean value among all respondents is indicated in the figure. Whiskers indicate $95 \%$ confidence intervals.

foreign-born parents), and 11 ppt more to state 'grandparents can take care of the child' (4 ppt less likely for foreign parents). ${ }^{21}$ Differences in these factors help to explain the differences in demand gaps by family background. However, they neither explain why there are different enrolment gaps nor why enrolment gaps exist conditional on demand. An initial insight into the role of supply-side factors is provided by the fact that less-educated parents and foreign-born parents are more likely to report availability (A), fees (F) and quality (Q) factors as reasons for not using day care, compared with more-educated and native-born parents, respectively. ${ }^{22}$ On the whole, availability and quality factors appear to be important for both groups, although perhaps comparatively more important for foreign-born parents over less-educated parents. Fees are also important for both, although the difference in

\footnotetext{
${ }^{21}$ Such differences are consistent with findings from previous studies (e.g. Schober and Spieß, 2013).

${ }^{22}$ As explained in the introduction, we categorise willingness to pay and parental fees as supply-side explanations in line with the institutional context.
} 
willingness to pay is greater by parental education than country of birth. Unfortunately we lack good data on day care quality. However, in the next section we investigate the impact of the other supply-side factors (availability and fees) on enrolment gaps.

\section{The impact of supply-side barriers on enrolment gaps}

\subsection{Local day care shortages}

To investigate the impacts of county-level shortages on day care enrolment gap, we start out running a pooled OLS estimation:

$$
Y_{i c s t}=\alpha_{0}+\alpha_{1} L_{i}+\alpha_{2} S_{c t}+\alpha_{3}\left(L_{i} * S_{c t}\right)+X_{i c t}^{\prime} \alpha_{4}+\lambda_{s t}+\epsilon_{i c s t}
$$

where $Y_{i c s t}$ is day care enrolment of child $i$ from county $c$ in state $s$ in year $t, L_{i}$ is an

indicator of either less-educated or foreign-born parents, $S_{c t}$ are county-level shortages, $X_{i c t}^{\prime}$ is a vector of exogenous household controls (i.e. the age of the child in three categories and its gender as well as the marital status of the respondent) and county-level controls (explained below), and $\lambda_{s t}$ are state-year effects. The coefficient of interest, $\alpha_{3}$, indicates whether the enrolment gap depends on the county-level shortages. The parameter is inconsistently estimated if shortages are correlated with unobserved determinants of the enrolment gap in the error term $\epsilon_{i c s t}$.

Beyond shortages, the enrolment gap may be determined by supply-side factors, such as fees, opening hours, and day care quality, that are determined by state and municipality rules as well as local providers. Another important supply-side factor that may impact disproportionately on less-educated or foreign parents is proximity of day care, which itself may depend on the density of the municipality. On the demand-side, differences by family background in the share of parents who have no wish for day care may depend in some way on differences in local norms towards maternal labour market attachment. To some extent, 
Table 2: Reasons for not using day care

\begin{tabular}{|c|c|c|c|c|c|c|c|c|}
\hline \multirow[t]{2}{*}{ Family background } & \multirow[b]{2}{*}{$(1)$} & \multirow{2}{*}{$\begin{array}{l}\text { All } \\
(2)\end{array}$} & \multicolumn{3}{|c|}{ Education } & \multicolumn{3}{|c|}{ Migration background } \\
\hline & & & $\begin{array}{l}\text { High } \\
(3)\end{array}$ & $\begin{array}{c}\text { Less } \\
(4)\end{array}$ & $\begin{array}{c}(4)-(3) \\
(5)\end{array}$ & $\begin{array}{l}\text { No } \\
(6)\end{array}$ & $\begin{array}{l}\text { Yes } \\
(7)\end{array}$ & $\begin{array}{c}(7)-(6) \\
(8)\end{array}$ \\
\hline \multicolumn{9}{|l|}{ Would use day care if ... } \\
\hline if day care was for free $(F)$ & 17496.00 & 0.15 & 0.12 & 0.18 & $0.05 * * *$ & 0.14 & 0.22 & $0.08 * * *$ \\
\hline if the child had a full-day slot (A) & 17310.00 & 0.09 & 0.08 & 0.10 & $0.03^{* * *}$ & 0.08 & 0.14 & $0.06^{* * *}$ \\
\hline if the child had a half-day slot (A) & 17281.00 & 0.15 & 0.13 & 0.17 & $0.05 * * *$ & 0.13 & 0.23 & $0.09 * * *$ \\
\hline if opening hours were more suitable (A) & 17240.00 & 0.17 & 0.14 & 0.19 & $0.06^{* * *}$ & 0.15 & 0.25 & $0.10^{* * *}$ \\
\hline if day care institution was nearby (A) & 17111.00 & 0.14 & 0.10 & 0.17 & $0.06^{* * *}$ & 0.11 & 0.26 & $0.15^{* * *}$ \\
\hline if registration / application was easier (A) & 4527.00 & 0.18 & 0.14 & 0.22 & $0.08 * * *$ & 0.15 & 0.34 & $0.19^{* * *}$ \\
\hline if staff was multilingual $(\mathrm{Q})$ & 17078.00 & 0.07 & 0.05 & 0.09 & $0.03^{* * *}$ & 0.05 & 0.18 & $0.13^{* * *}$ \\
\hline if groups were smaller $(\mathrm{Q})$ & 17180.00 & 0.18 & 0.16 & 0.20 & $0.04^{* * *}$ & 0.17 & 0.27 & $0.10^{* * *}$ \\
\hline if culture / religion was considered more (Q) & 17066.00 & 0.05 & 0.03 & 0.07 & $0.04^{* * *}$ & 0.03 & 0.13 & $0.10^{* * *}$ \\
\hline \multicolumn{9}{|l|}{ Reasons for not using day care } \\
\hline Did not get a spot $(\mathrm{A})$ & 26389.00 & 0.11 & 0.10 & 0.12 & $0.01 * *$ & 0.10 & 0.15 & $0.05^{* * *}$ \\
\hline Insufficient opening hours (A) & 31056.00 & 0.07 & 0.06 & 0.08 & $0.02^{* * *}$ & 0.07 & 0.07 & 0.00 \\
\hline I'm home myself $(\mathrm{D})$ & 26454.00 & 0.61 & 0.53 & 0.68 & $0.15^{* * *}$ & 0.60 & 0.65 & $0.05^{* * *}$ \\
\hline Want to raise child myself (D) & 31125.00 & 0.75 & 0.72 & 0.78 & $0.07 * * *$ & 0.75 & 0.78 & $0.03^{* *}$ \\
\hline Child is too young (D) & 31375.00 & 0.85 & 0.86 & 0.84 & $-0.02^{* * *}$ & 0.85 & 0.84 & -0.01 \\
\hline Child should spent time with siblings (D) & 22242.00 & 0.36 & 0.31 & 0.40 & $0.10^{* * *}$ & 0.35 & 0.45 & $0.10^{* * *}$ \\
\hline Grandparents can take care of child (D) & 23833.00 & 0.32 & 0.26 & 0.37 & $0.11^{* * *}$ & 0.33 & 0.28 & $-0.04 * * *$ \\
\hline Fear of negative influences (D) & 4614.00 & 0.07 & 0.05 & 0.09 & $0.04^{* * *}$ & 0.06 & 0.12 & $0.05^{* *}$ \\
\hline Insufficient support at institution (Q) & 4606.00 & 0.11 & 0.11 & 0.11 & -0.00 & 0.10 & 0.13 & 0.03 \\
\hline Insufficient consideration of culture (Q) & 4613.00 & 0.02 & 0.01 & 0.03 & $0.02 * * *$ & 0.01 & 0.08 & $0.07^{* * *}$ \\
\hline \multicolumn{9}{|l|}{ Willingness to pay } \\
\hline Maximum fee for a day care spot $(\mathrm{F})$ & 1479.00 & 172.63 & 224.01 & 141.95 & $-82.06^{* * *}$ & 184.31 & 145.28 & $-39.02^{* * *}$ \\
\hline
\end{tabular}

Notes: $D$ indicates a demand reason. We regard $Q$ (quality), $F$ (fees) and $A$ (availability) as supply-side barriers. Education denotes the highest schooling degree and migration backgrounds indicates whether both parents are foreign-born. Columns (2)-(4) and (6)-(7) show the share of affirmative responses for the corresponding questions. Multiple affirmative responses are possible. Columns (5) and (8) show the difference between the groups $\left({ }^{* *} p<0.01,{ }^{* *} p<0.05,{ }^{*} p<0.1\right.$.). All questions are only asked conditional on the child not being enrolled in day care. 
this may be the result of household sorting but also of longstanding cultural differences, i.e. between East and West Germany and indeed of local labour market conditions themselves, all of which may impact differentially by family background.

If any of these factors are related to shortages then there will be confounding relationships. An example of a downward bias is if a lack of affordable housing means that denser urban municipalities struggle to hire enough teachers to keep up with demand for slots (high shortages) but that the generally close proximity of day care centres in denser municipalities is favourable to less-educated enrolment (lower enrolment gap). An example of an upwards bias is if there is less political will to expand provision of day care in traditionally conservative areas (high shortages) and if the prevalence of conservative gender norms disproportionately affects labour market participation of less-educated mothers (higher enrolment gap). But bias of any direction is potentially plausible.

Some of these issues will be controlled for by the state-year fixed effects. For example, in cases where rules are determined at the state level or where cultural norms vary at a coarse level. To account for some remaining potentially confounding relationships we additionally include county-level controls in $X_{i c t}$ : an urban-rural indicator, and indicators for the GDP tercile of counties within the state, plus interactions between the two county controls with the family background (to account for differential effects, i.e. on the enrolment gap). Finally, to deal with remaining unobservable covariates that could vary within state-year cells, such as local norms or day care quality, we additionally include county fixed-effects in our preferred specification:

$$
Y_{i c s t}=\beta_{0}+\beta_{1} L_{i}+\beta_{2} S_{c t}+\beta_{3}\left(L_{i} * S_{c t}\right)+X_{i c t}^{\prime} \beta_{4}+\mu_{c}+\lambda_{s t}+\varepsilon_{i c s t}
$$

where $\mu_{c}$ denotes county fixed effects.

The identifying assumption is that time-variation in shortages within a county is uncorrelated with unobservables that impact day care enrolment differently by family background. 
We argue that this is plausible since time-variation in shortages within counties should largely reflect differences in the timing of roll-out of day care spots in response to the federal level introduction of a legal entitlement to day care. Unobserved demand and supply factors that affect the enrolment gaps such as local norms and day care quality are likely to be relatively fixed over a short period. Differences in speed or timing of roll-out are used in several previous studies as a source of variation in day care supply that is exogenous to day care quality or other factors that impact on child development (e.g. Cornelissen et al., 2018; Felfe and Lalive, 2018).

Table 3 presents results from pooled OLS regressions based on equation (1) and county fixed effects regression based on equation (2). Column (2) reports a negative and highly significant relationship between regional day care shortages and the enrolment gap for children from less-educated parents using the pooled OLS model. Specifically, an increase in shortages by 10 ppt is associated with a decrease in day care enrolment gap by parental education of about 5 ppt. Column (4) reports the results with county fixed effects where the identifying variation comes from changes in shortages within counties over time. The results are very similar to the pooled OLS estimates and indicate that regional day care shortages have a significant impact on the enrolment gap by parental education. As shown in Appendix Table A4, very similar patterns emerge when differentiating by whether the respondent parent has a university degree. ${ }^{23}$ Further, results are also robust to using the stricter demand measure, see Section 3, to calculate shortages despite much lower observation numbers (results are available upon request).

Columns (5)-(8) of Table 3 examine the role of regional shortages for enrolment gaps by parental country of birth. In contrast to the estimates by educational background, the results

\footnotetext{
${ }^{23}$ As a robustness check, appendix Table A5 also shows coefficients when shortages are calculated leaving individual $i$ out of the calculation, i.e. $S_{-i c t}=\frac{1}{N-1} \sum_{n \neq i}^{N} S_{\text {Shortage }}$. We prefer to use unadjusted shortages as the main specification since the leave-one-out version introduces an unintended source of variation in our fixed-effects estimation. Specifically, individuals that are enrolled will mechanically have a higher shortage than individuals who are not enrolled in the same county. Nevertheless, the coefficients of interest (interaction of the family background with shortages) remain virtually unchanged.
} 
Table 3: Day care enrolment, family background and regional shortages

\begin{tabular}{|c|c|c|c|c|c|c|c|c|}
\hline \multirow[b]{2}{*}{ Mean of dep. var } & \multicolumn{8}{|c|}{ Day care enrolment } \\
\hline & $\begin{array}{c}(1) \\
0.375\end{array}$ & $\begin{array}{c}(2) \\
0.375\end{array}$ & $\begin{array}{c}(3) \\
0.375\end{array}$ & $\begin{array}{c}(4) \\
0.375\end{array}$ & $\begin{array}{c}(5) \\
0.376\end{array}$ & $\begin{array}{c}(6) \\
0.376\end{array}$ & $\begin{array}{c}(7) \\
0.376\end{array}$ & $\begin{array}{c}(8) \\
0.376\end{array}$ \\
\hline Less educated & $\begin{array}{c}-0.105^{* * *} \\
(0.021)\end{array}$ & $\begin{array}{l}-0.035 \\
(0.025)\end{array}$ & $\begin{array}{c}-0.097^{* * *} \\
(0.021)\end{array}$ & $\begin{array}{l}-0.038 \\
(0.025)\end{array}$ & & & & \\
\hline Less educated $\times$ shortage & & $\begin{array}{c}-0.005^{* * *} \\
(0.001)\end{array}$ & & $\begin{array}{c}-0.004^{* * *} \\
(0.001)\end{array}$ & & & & \\
\hline Migration background & & & & & $\begin{array}{c}-0.093^{* *} \\
(0.043)\end{array}$ & $\begin{array}{c}-0.090^{*} \\
(0.049)\end{array}$ & $\begin{array}{c}-0.086^{*} \\
(0.045)\end{array}$ & $\begin{array}{c}-0.086^{*} \\
(0.052)\end{array}$ \\
\hline Migration $\times$ shortage & & & & & & $\begin{array}{c}-0.000 \\
(0.001)\end{array}$ & & $\begin{array}{c}0.000 \\
(0.001)\end{array}$ \\
\hline Shortage & $\begin{array}{c}-0.005^{* * *} \\
(0.001)\end{array}$ & $\begin{array}{c}-0.002^{* * *} \\
(0.001)\end{array}$ & $\begin{array}{c}-0.005^{* * *} \\
(0.001)\end{array}$ & $\begin{array}{c}-0.003^{* * *} \\
(0.001)\end{array}$ & $\begin{array}{c}-0.005^{* * *} \\
(0.001)\end{array}$ & $\begin{array}{c}-0.005^{* * *} \\
(0.001)\end{array}$ & $\begin{array}{c}-0.004^{* * *} \\
(0.001)\end{array}$ & $\begin{array}{c}-0.004^{* * *} \\
(0.001)\end{array}$ \\
\hline State $\times$ wave FEs & $\mathrm{Y}$ & $\mathrm{Y}$ & $\mathrm{Y}$ & $\mathrm{Y}$ & $\mathrm{Y}$ & $\mathrm{Y}$ & $\mathrm{Y}$ & $\mathrm{Y}$ \\
\hline County FEs & & & $\mathrm{Y}$ & $\mathrm{Y}$ & & & $\mathrm{Y}$ & $\mathrm{Y}$ \\
\hline Observations & 43,668 & 43,668 & 43,668 & 43,668 & 42,845 & 42,845 & 42,845 & 42,845 \\
\hline
\end{tabular}

Note: County-level correlates based on equations (1) and (2). Migration background indicates that both parents are born abroad and non-Western. The sample is restricted to a minimum of 50 observations per county (Appendix Figure A4 shows robustness to different cut-offs). All estimates control for the sex and age of the child, marital status of the respondent and county level controls (urban indicator and GDP tercile within the state) interacted with the family background. Standard errors, clustered at the individual level, in parentheses. ${ }^{* * *} p<0.01,{ }^{* *} p<0.05,{ }^{*} p<0.1$.

suggest that regional shortages play a minor role in explaining the foreign-born parents enrolment gap. The foreign-born interaction with regional shortages is not significant and very close to zero in both empirical specifications (using state by wave or county and wave fixed effects). Appendix Table A4 shows estimates based on the indicator "German not main language at home." Again, results are robust to using this alternative measure of migrant family background. ${ }^{24}$

We further examine alternative specifications to investigate potential non-linear effects of shortages and fees estimating a model with shortages as a binomial:

$$
\begin{aligned}
Y_{i c s t}= & \gamma_{0}+\gamma_{1} L_{i}+\gamma_{2} S_{c t}+\gamma_{3} S_{c t}^{2}+\gamma_{4}\left(L_{i} * S_{c t}\right) \\
& +\gamma_{5}\left(L_{i} * S_{c t}^{2}\right)+X_{i c t}^{\prime} \gamma_{6}+\mu_{c}+\lambda_{s t}+u_{i c s t}
\end{aligned}
$$

\footnotetext{
${ }^{24}$ Additionally, results are also robust to imposing the restriction that both parents have to be nonEuropean (in contrast to the current definition of parents being non-Western European and non-North American). These results are available upon request.
} 
We also estimate a semi-parametric model:

$$
Y_{i c s t}=\sum_{b} \delta_{b} S_{b, c t}+\sum_{b} \pi_{b}\left(L_{i} * S_{b, c t}\right)+X_{i c t}^{\prime} \sigma+\mu_{c}+\lambda_{s t}+e_{i c s t}
$$

where $S_{b}$ are bins for shortages 5 percentage points in width. The advantage of the nonlinear specifications is to gain insight into the effect size at different initial levels of shortages. For example, the non-linear specification might reveal that marginal changes have little effect on the enrolment gap at high levels of shortages, suggesting that only a large change would be effective.

Figure 3 presents the results of the estimation of equation (3) and equation (4). For the less-educated parents group, there appears to be a clear non-linear relationship between the day care enrolment gap and local shortages. Specifically, the enrolment gap is close to zero and not statistically significant when shortages are very low and then quickly increases to around 10 ppt before effectively flattening out at higher levels of shortages (above about 20 ppt). The binomial specification finds a zero intercept (in contrast to the less flexible linear specification) and the enrolment gap in the first shortages bin (0 ppt-5 ppt) is insignificant. This implies that the enrolment gap may be substantially reduced when shortages are zero. For the foreign-born parents category, a very different picture emerges: the enrolment gap is fairly flat at about $10 \mathrm{ppt}$ at all levels of shortages. This is consistent with findings from the linear model in Table 3.

Overall the findings suggest that reducing regional day care shortages lowers the enrolment gap for children of less-educated parents substantially, but it does not help to reduce the migrant-native enrolment gap. We discuss interpretations of these results in section 6 .

\subsection{Day care fees}

Next we focus on the role of day care fees as a determinant of the enrolment gap. Due to the lack of time variation in the fee data we analyse the effect of a substantial reduction 
Figure 3: The enrolment gap by parental background at different levels of shortages

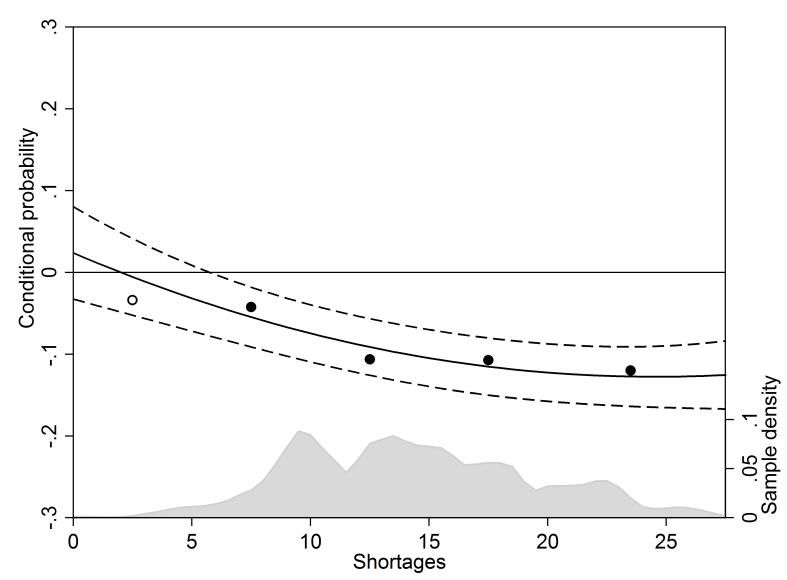

(a) Less-educated parents

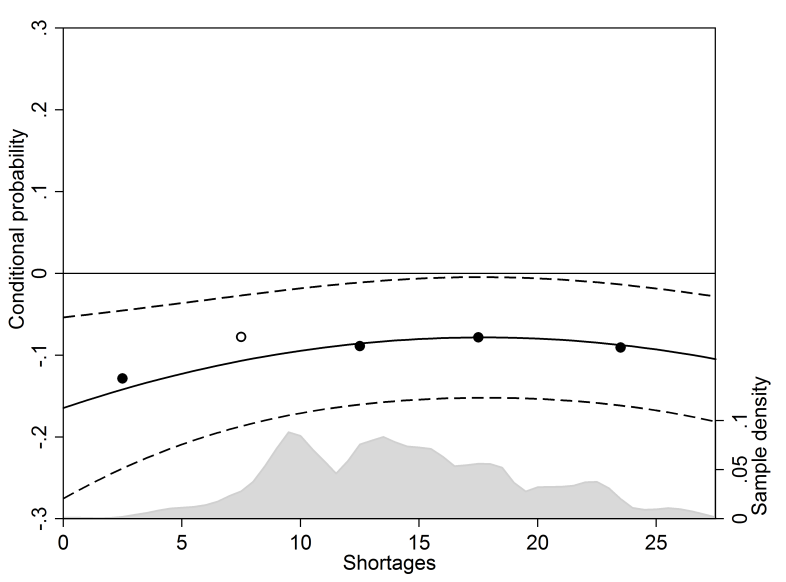

(b) Both parents born abroad

Notes: Graphical illustrations of the results of the estimation equation (3) and equation (4). The solid line plots the enrolment gap by (a) parental education and (b) parental country of birth against shortages and is equal to $E\left[Y_{i c s t} \mid L_{i t}=1\right]-E\left[Y_{i c s t} \mid L_{i c t}=0\right]=\gamma_{1}+\gamma_{4} \times S_{c t}+\gamma_{5} \times S_{c t}^{2}$. The dashed lines represent the $10 \%$ confidence intervals reflecting meaningful standard errors computed for marginal effects following Aiken and West (1991). The markers plot the enrolment gap in each shortages bin $b$, i.e. the parameters $\delta_{1 b}$. The filled markers are significant at the $10 \%$ level whereas the empty markers are insignificant. The grey area represents a kernel density plot of the sample distribution.

in fees using the synthetic control method. Specifically, we examine the case of the federal state of Hamburg, where fees were abolished for the first five hours of care per day in August $2014 .{ }^{25}$ Hamburg was the only state to change its fees regulation during our sample window of 2012-2016. ${ }^{26}$ For those enrolled in half-day care, fees were eliminated completely, and for those enrolled in more than half-day care, fees were reduced by an amount equal to the halfday fee they would have paid previously (depending on the household income and number of persons in the household). Thus, all parents of children 0-2 had a significant fee reduction.

Since Hamburg has a fixed fee regulation, only dependent on net household income and

\footnotetext{
${ }^{25}$ Each German federal state independently sets broad regulations for day care fees, e.g. which types of households are exempted from fees. The detailed fee structure itself is set at a more regional level. Typically, fees vary by hours of day care enrolment, household income and other household characteristics (see Section 2 for more details). Beginning in 2005, some states started abolishing day care fees, initially for older children, subsequently for younger children.

${ }^{26}$ Before 2012, three states had abolished fees for the last day care year (6 years old), two states (Berlin and Hamburg) had abolished fees for the last three years (3-6 years old), and Rhineland-Palatinate had abolished fees for the last five years (1-6 years old). For Hamburg, fees were abolished for the first five hours of daily care only, while the other states abolished fees for all-day care.
} 
household size (which we have in our data), we are able to compute the theoretical reduction in fees for all Hamburg children in our sample (including those not in day care). Monthly fees for the average household were reduced by a total of 178 Euros (63\% of the pre-reform fees). For the children of less-educated parents in our sample, fees are reduced by 162 Euros and for the children of better-educated parents, the reduction amounts to 184 Euros. When expressed as a share of net income, fees are reduced by 0.044 overall, 0.043 for children of less-educated parents and 0.047 for children of better-educated parents. Thus, the relative magnitude of the reduction was roughly comparable for both groups.

The large reduction of fees in Hamburg provides a quasi-random treatment that we use to estimate the impact of fees on the enrolment gap using the synthetic control method of Abadie et al. (2010). Specifically, we examine the evolution of the enrolment gap for Hamburg ( $N=3,724$ for Hamburg) before and after the reduction of fees, comparing it to the evolution for a synthetic Hamburg constructed as a weighted average of the remaining federal states, none of which changed their fees in the sample window. The weights for creating synthetic Hamburg are chosen so as to best approximate the real Hamburg based on pre-treatment values of the outcome variable and covariates. ${ }^{27}$ Following Kaul et al. (2015), we choose two of the three available pre-treatment outcomes (2012 and 2014) and four covariates (unemployment, population density, GDP per capita, and migration share) to be used in selecting the weights matrix. The resultant weights are reported in Table 4 .

Figure 4 shows the results by parental education. Panels (a), (b), and (c) plot the evolution of enrolment from less-educated parents, enrolment from better-educated parents, and the enrolment gap, respectively, over time for Hamburg and synthetic Hamburg. Each light grey line plots the estimated effect when carrying out the synthetic control method using one of the 15 non-treated control federal states as a placebo treatment, following Abadie et al. (2010). ${ }^{28}$ These placebo treatment effects are used for statistical inference (also as Abadie

\footnotetext{
${ }^{27}$ Weights are chosen to minimise the mean squared prediction error (MSPE) for the outcomes variable over the pre-treatment period. For more detail on the process, see Abadie et al. (2010).

${ }^{28}$ Rather than plotting the placebo treatment effects on a separate chart with a baseline of zero, we plot them on the same chart using synthetic Hamburg as the baseline. Effectively we normalise the placebo
} 
et al., 2010), and the significance of post-intervention outcomes is marked on the plots. The figures show that enrolment of children from less-educated parents increases, while it holds constant for those from more-educated parents, and the enrolment gap decreases relative to the synthetic control. These differences emerge in the first post-intervention period and become statistically significant by the second post-intervention period. ${ }^{29}$ Overall, the average of both post-intervention periods suggests a decrease in the enrolment gap by 7.3 ppt. This is an economically significant effect size since it approximately halves the enrolment gap.

Between 2014 and 2016 the total number of slots held roughly steady in both Hamburg and the synthetic control states as shown by the enrolment figures in Table A1. Thus, the reduction of fees did not appear to coincide with an increase in slots. This fact may seem inconsistent with the increase in enrolment by less-educated parents in Hamburg relative to the control seen in Figure 4. However, this apparent difference is explained by the fact that there is also a slight decrease in enrolment by children from more-educated parents in Hamburg compared to the control group over the period (of around $1.5 \mathrm{ppt}$ ). Since the more-educated group represents the majority in Hamburg (a share of 0.72 compared with around 0.55 in the control states), the small decrease in attendance offsets the larger increase by the less-educated group. Thus we can be fairly sure that the drop in the enrolment gap is a fees effect since there are no correlated changes in supply.

To help provide a sense-check for the size of the estimate, we also carry out a pooled OLS regression of equation (1) using the information on fees reported for one wave in the place of the shortages variable. We report the results in appendix Table A7. Taking the estimate on the interaction between fees and less-educated parents from column (2) and multiplying it with the average fee reduction in Hamburg provides an expected reduction in the enrolment gap of $0.057 \times 1.78=10.1$, which is comparable to our synthetic control estimate.

We also carry out the synthetic control analysis for the enrolment gap by parental coun-

controls to synthetic Hamburg to visualise statistical inference on the same chart as the pre-trends.

${ }^{29}$ In the synthetic control method, significance levels are based on comparing the deviation between the treated unit and the synthetic control to the typical deviation between the donors and the synthetic control. 
Figure 4: The effect of fee elimination in Hamburg on the enrolment gap (by parental education)

(a) Less-educated parents

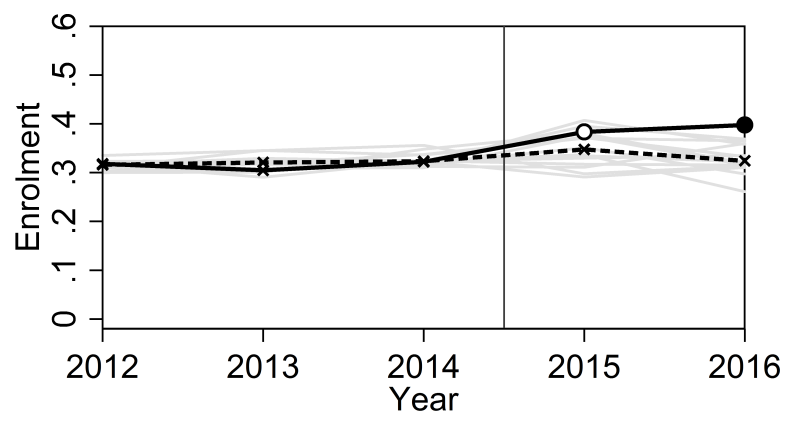

(b) More-educated parents

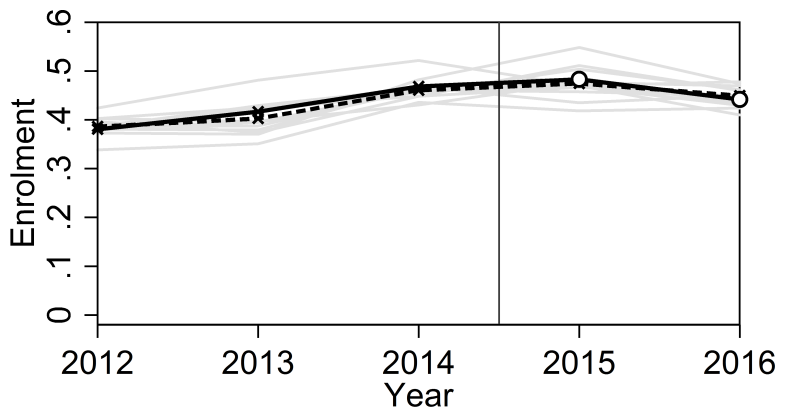

(c) Enrolment gap

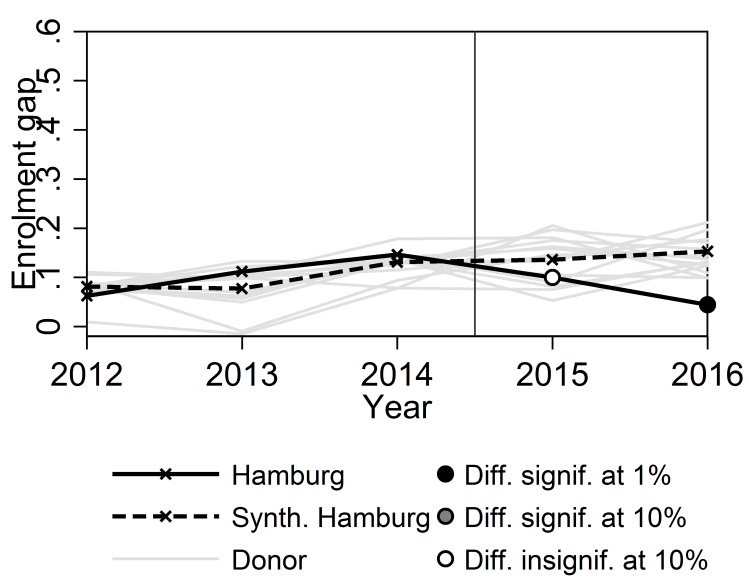

Notes: Figures show the evolution in Hamburg vs. synthetic Hamburg of (panel a) the enrolment rate of children from less-educated parents; (panel b) the enrolment rate of children from better-educated parents; and (panel c) the enrolment gap. All interviews for the 2014 wave occurred before fees were eliminated, making this the last wave with fees - as indicated by the vertical line. Weights for the synthetic Hamburg are reported in Table 4. Each light grey line plots the estimated effect (relative to synthetic Hamburg) when carrying out the synthetic control method using one of the 15 non-treated control federal states as a placebo treatment, following Abadie et al. (2010).

try of birth and present the results in Figure 5. The enrolment of children with migrant family background is unaffected by the change in fees. The native group sees an increase in enrolment; however the effect is small and does not seem to persist, nor is there a significant increase in the enrolment gap in any post-intervention period.

Overall, we conclude that reducing fees appears to have large effects on the enrolment gap by parental education, even when fees are income-dependent, but does not impact the 
Figure 5: The effect of fee elimination in Hamburg on the enrolment gap (by parental country of birth)

(a) Both parents born abroad

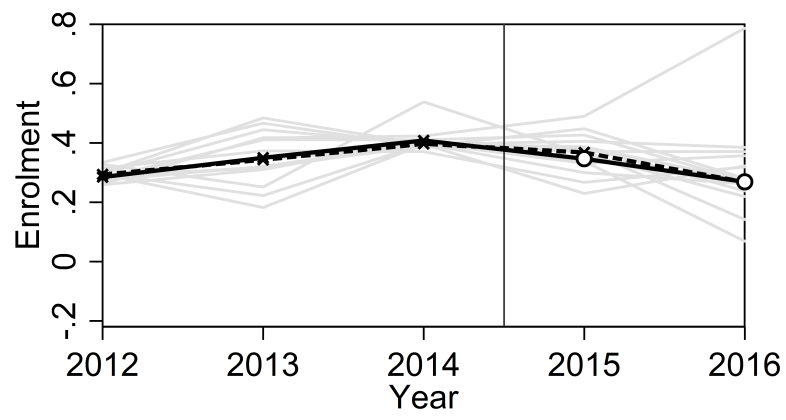

(b) At least one parent not born abroad

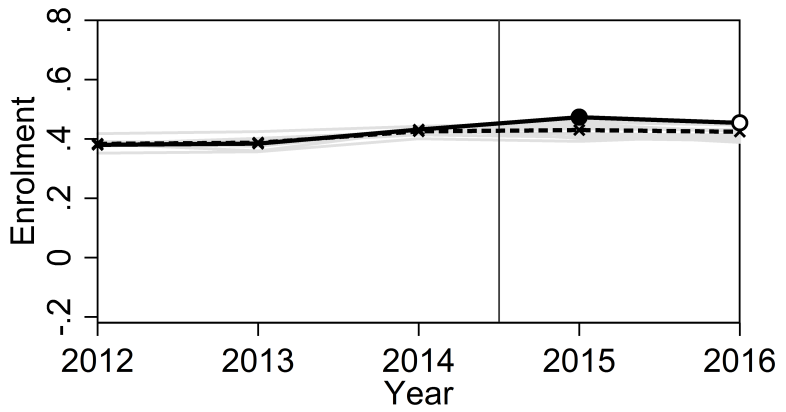

(c) Enrolment gap

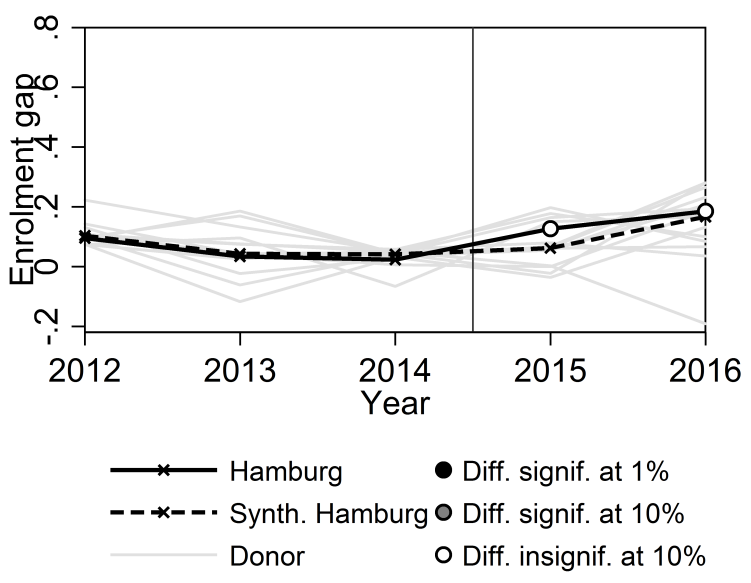

Notes: Figures show the evolution in Hamburg vs. synthetic Hamburg of (panel a) the enrolment rate of children with both parents born abroad; (panel b) the enrolment rate of children with at least one parent not born abroad; and (panel c) the enrolment gap. All interviews for the 2014 wave occurred before fees were eliminated, making it the last wave with fees - as indicated by the vertical line. Weights for the synthetic Hamburg are reported in Table 4. Each light grey line plots the estimated effect (relative to synthetic Hamburg) when carrying out the synthetic control method using one of the 15 non-treated control federal states as a placebo treatment, following Abadie et al. (2010).

enrolment gap by parental country of birth. Thus these results mirror those for the impacts of day care shortages in the previous section. 
Table 4: Synthetic Hamburg weights

\begin{tabular}{|c|c|c|c|c|c|c|}
\hline \multirow[b]{2}{*}{ State } & \multicolumn{3}{|c|}{ by parental education } & \multicolumn{3}{|c|}{ by parental country of birth } \\
\hline & Low & High & Gap & Foreign & Native & Gap \\
\hline Schleswig-Holstein & 0 & 0 & 0 & 0 & 0 & 0 \\
\hline Lower Saxony & 0 & 0 & 0 & 0 & 0.389 & 0 \\
\hline Bremen & 0.239 & 0 & 0.393 & 0 & 0 & 0 \\
\hline North Rhein-Westphalia & 0 & 0 & 0 & 0 & 0 & 0 \\
\hline Hesse & 0 & 0 & 0 & 0 & 0 & 0 \\
\hline Rhineland-Palatinate & 0 & 0 & 0 & 0 & 0 & 0 \\
\hline Baden-Württemberg & 0 & 0 & 0.334 & 0.288 & 0 & 0.313 \\
\hline Bavaria & 0.363 & 0 & 0 & 0 & 0 & 0.142 \\
\hline Saarland & 0 & 0.636 & 0 & 0 & 0 & 0 \\
\hline Berlin & 0 & 0 & 0 & 0.510 & 0.439 & 0.392 \\
\hline Brandenburg & 0.0580 & 0.364 & 0.273 & 0.202 & 0.171 & 0.153 \\
\hline Mecklenburg-Vorpommern & 0 & 0 & 0 & 0 & 0 & 0 \\
\hline Saxony & 0 & 0 & 0 & 0 & 0 & 0 \\
\hline Saxony-Anhalt & 0.340 & 0 & 0 & 0 & 0 & 0 \\
\hline Thuringia & 0 & 0 & 0 & 0 & 0 & 0 \\
\hline
\end{tabular}

\section{Interpretation of the results and policy suggestions}

The results from the enrolment gap by parental country of birth are somewhat less straightforward to interpret. The enrolment gap by country of birth is (a) not reflected in a significant demand gap, (b) still there at low levels of shortages, (c) not bigger or smaller at higher levels of shortages, and (d) not bigger or smaller after a big reduction in fees. Any explanation for the enrolment gap for foreign-born parents needs to be able to fit these four facts.

Firstly, the lack of a significant demand gap allows us to rule out that the enrolment gap is because foreign-born parents do not want a place due to different preferences. One might worry that stated preferences reflect parental aspirations and not actual willingness to enrol. However, this does not seem consistent with the fact that $95 \%$ of parents that indicate a demand, also report having made applications to day care centres.

Secondly, enrolment is not well explained by differences in search effectiveness, since the enrolment gap is unaffected by the level of shortages. Factors such as being well-networked and knowing to apply extremely early are likely to give applications from native-born an 'edge' when shortages are high. Thus, if the enrolment gap was due to these factors one 
would expect it to decrease as shortages lessen-but it doesn't. Other possible factors, such as a complete lack of understanding of the application process or a complete lack of German language, may continue to be important even with low shortages if they prevent foreign parents from applying at all. However, this is not consistent with the fact that almost all parents that demand a spot have also managed to submit at least one application.

Thirdly, we cannot rule out discrimination as an explanation for the enrolment gap. If discrimination against foreign-born parents is strong enough, then it would result in an enrolment gap that does not necessarily get smaller with marginal increases in the availability of places. Foreign-born parents will struggle to find a place even at relatively low level of shortages if they are at the 'back of the queue' for any spot as a result of discrimination. Thus, if discrimination does explain the enrolment gap then it should be of a form stronger than that faced by less-educated parents, on average. ${ }^{30}$ This would be consistent with the literature that shows discrimination against ethnic minorities in a wide range of contexts in education, including at day care centres (e.g. Batsaikhan et al., 2019, for Denmark).

Fourthly, it appears that financial concerns are no more or less important for foreign parents than other parents, based on the result that eliminating fees does not lower the gap in enrolment. This is somewhat consistent with the fact that the difference in maximum willingness to pay for a day care spot between foreign-born parents and other parents is smaller than the same difference by education (Table 2).

Fifthly, there may be further barriers to access that exist even in areas of low shortages. One possibility is day care quality. Even if parents report wanting a day care spot, and spots are available and affordable, they will not enrol their children if they find the quality to be too low. In fact, Table 2 shows that foreign-born parents are more likely than other parents to report any of the quality indicators (Q) such as group size, opening hours, and proximity of care as reasons for not enrolling their children in day care. Gaps by parental education

\footnotetext{
${ }^{30}$ We are not able to distinguish between different reasons for discrimination e.g. if centres make assumptions about workload based on parent characteristics (statistical discrimination), or if they hold implicit or explicit racial bias (taste-based discrimination).
} 
also exist, but they are always smaller. One potential explanation for these differences is that foreign-born parents place a greater emphasis on quality compared with other parents. However, it could also be that foreign-born parents live in areas with lower day care quality, making these concerns more prevalent. Foreign-born parents may also have specific quality concerns. Indeed, foreign parents are three to four times more likely than other parents to cite "if staff were multilingual" and "if culture/religion were considered more" as factors that would lead them to enrol. Notably, citing these quality factors does not seem to be related to lower parental demand for day care, suggesting parents see these as supply-side issues.

In terms of policy recommendations, one should expand availability and reduce fees to close the enrolment gap by parental education. The policy recommendations for the enrolment gap by parental country of birth, however, are a little more tentative. Ensuring adequate availability and affordability of care are surely an important starting point. However, our results imply that this is unlikely to be enough. To close the gap, policymakers should consider ensuring that day care centres deliver adequate high-quality care for all children respective of diverse cultures. Assistance in the application process itself could help if some parents struggle with understanding the system or the German language. Indeed, a third of foreign-born parents state that they would be using day care if the application process was easier (Table 2). Assistance like this could perhaps be provided by family centres and during home visits by midwives following birth. Finally, diversity training for staff may be an effective approach to tackle discrimination.

\section{Conclusion}

Despite expansions in day care provision for the under-three age group in Germany, there are substantial gaps in day care enrolment by family background. We show that demand for day care cannot fully account for enrolment gaps. Our results suggest that day care fees and local day care shortages play a significant role in explaining gaps by parental education. 
Reducing day care fees (or a more progressive fee structure) and reducing regional day care shortages can lower enrolment gaps by parental education substantially. However, enrolment gaps by parental country of birth are less affected by changes in local supply-side factors. We interpret our results and discuss policy measures for addressing enrolment gaps in each case.

Given the great potential of high-quality day care to reduce inequalities in later life outcomes by family background, it is important to have a thorough understanding of why enrolment gaps in day care exist and how to reduce them. Our study provides a first comprehensive analysis based on large sample data. We capture important supply-side factors: the availability of day care slots and parental fees. One factor that we do not observe is the quality of the day care centres. Further, we know little about the magnitude and type of discrimination facing less-educated or foreign-born parents. Our results suggest that these factors may be important, particularly for the enrolment of children of foreign-born parents. Field experiments could contribute to filling this gap and help to better understand the nature of enrolment gaps in day care, while also proposing solutions to reduce them. We leave this for future research. 


\section{References}

Abadie, A., Diamond, A., and Hainmueller, J. (2010). Synthetic control methods for comparative case studies: Estimating the effect of california's tobacco control program. Journal of the American Statistical Association, 105(490):493-505.

Abrassart, A. and Bonoli, G. (2015). Availability, cost or culture? obstacles to childcare services for low-income families. Journal of Social Policy, 44(4):787-806.

Aiken, L. S. and West, S. G. (1991). Multiple regression: Testing and interpreting interactions. Sage.

Alt, C., Bethmann, A., Gedon, B., Hubert, S., Hüsken, K., and Lippert, K. (2018). Kinderbetreuungsstudie. Längsschnittdatensatz 2012-2016. Version: 1. DJI - Deutsches Jugendinstitut. Dataset.

Alt, C., Gesell, D., Hubert, S., Hüsken, K., Kuhnke, R., and Lippert, K. (2017). DJIKinderbetreuungsreport 201\%. Inanspruchnahme und Bedarfe aus Elternperspektive. Deutsches Jugendinstitut (DJI), München.

Andersen, S. C. and Guul, T. S. (2019). Reducing minority discrimination at the front line - combined survey and field experimental evidence. Journal of Public Administration Research and Theory.

Autorengruppe Bildungsberichterstattung (2018). Bildung in Deutschland 2018. Ein indikatorengestützter Bericht mit einer Analyse zu Wirkungen und Erträgen von Bildung.

Bainbridge, J., Meyers, M. K., Tanaka, S., and Waldfogel, J. (2005). Who gets an early education? family income and the enrollment of three-to five-year-olds from 1968 to 2000. Social Science Quarterly, 86(3):724-745.

Batsaikhan, M., Gørtz, M., Kennes, J., Lyng, R. S., Monte, D., and Tumennasan, N. (2019). Daycare choice and ethnic diversity: Evidence from a randomized survey. Economics Working Papers 2019-02, Department of Economics and Business Economics, Aarhus University.

Becker, G. S. (1975). Front matter, human capital: a theoretical and empirical analysis, with special reference to education. In Human Capital: A Theoretical and Empirical Analysis, with Special Reference to Education, Second Edition, pages 22-0. NBER. 
Björklund, A. and Salvanes, K. G. (2011). Education and family background: Mechanisms and policies. In Handbook of the Economics of Education, volume 3, pages 201-247. Elsevier.

Boneva, T. and Rauh, C. (2017). Socio-economic gaps in university enrollment: The role of perceived pecuniary and non-pecuniary returns. CESifo Working Paper Series No. 6756.

Boneva, T. and Rauh, C. (2018). Parental beliefs about returns to educational investments - the later the better? Journal of the European Economic Association, 16(6):1669-1711.

Bradbury, B., Corak, M., Waldfogel, J., and Washbrook, E. (2015). Too many children left behind: The US achievement gap in comparative perspective. Russell Sage Foundation.

Carneiro, P. M. and Heckman, J. J. (2003). Human capital policy. NBER working paper No. w9495.

Cornelissen, T., Dustmann, C., Raute, A., and Schönberg, U. (2018). Who benefits from universal child care? estimating marginal returns to early child care attendance. Journal of Political Economy, 126(6):2356-2409.

Cunha, F., Elo, I., and Culhane, J. (2013). Eliciting maternal expectations about the technology of cognitive skill formation. NBER Working Paper 19144.

Cunha, F. and Heckman, J. (2007). The technology of skill formation. American Economic Review, $97(2): 31-47$.

Felfe, C. and Lalive, R. (2018). Does early child care affect children's development? Journal of Public Economics, 159:33-53.

Fugger, N., Klein, T., and Riehm, T. (2017). Dezentrale Kitaplatzvergabe ohne Warteschlange: Ein Leitfaden. ZEWpolicybrief, (4):709-745.

Greenberg, J. P. (2011). The impact of maternal education on children's enrollment in early childhood education and care. Children and Youth Services Review, 33(7):1049-1057.

Hanushek, E. A., Peterson, P. E., Talpey, L. M., and Woessmann, L. (2019). The unwavering ses achievement gap: Trends in us student performance. NBER working paper 25648.

Havnes, T. and Mogstad, M. (2011). No child left behind: Subsidized child care and children's long-run outcomes. American Economic Journal: Economic Policy, 3(2):97-129.

Havnes, T. and Mogstad, M. (2015). Is universal child care leveling the playing field? Journal of Public Economics, 127:100-114. 
Herzog, S. and Klein, T. (2018). Matching practices for childcare - germany. Matching in practice, MiP Country Profile 26.

Kaul, A., Klößner, S., Pfeifer, G., and Schieler, M. (2015). Synthetic Control Methods: Never Use All Pre-Intervention Outcomes Together With Covariates. MPRA Paper 83790, University Library of Munich, Germany.

Kluve, J. and Schmitz, S. (2018). Back to work: Parental benefits and mothers' labor market outcomes in the medium run. ILR Review, 71:143-173.

Machin, S. and Vignoles, A. (2004). Educational inequality: the widening socio-economic gap. Fiscal Studies, 25(2):107-128.

Magnuson, K. and Waldfogel, J. (2016). Trends in income-related gaps in enrollment in early childhood education: 1968 to 2013. AERA Open, 2(2):2332858416648933.

OECD (2016). Childcare costs are around 15OECD. OECD Publishing, Paris.

OECD (2018). Engaging Young Children. OECD Publishing, Paris.

OECD (2019). Net childcare costs (indicator).

Pavolini, E. and Van Lancker, W. (2018). The matthew effect in childcare use: a matter of policies or preferences? Journal of European Public Policy, 25(6):878-893.

Phillips, D. A., Shonkoff, J. P., et al. (2000). From neurons to neighborhoods: The science of early childhood development. National Academies Press.

Schmitz, S., Spieß, C. K., and Stahl, J. F. (2017). Day care centers: Family expenditures increased significantly at some points between 1996 and 2015. DIW Economic Bulletin, 7(42):411-423.

Schober, P. S. and Spieß, C. K. (2013). Early childhood education activities and care arrangements of disadvantaged children in germany. Child Indicators Research, 6(4):709-735.

Sibley, E., Dearing, E., Toppelberg, C. O., Mykletun, A., and Zachrisson, H. D. (2015). Do increased availability and reduced cost of early childhood care and education narrow social inequality gaps in utilization? evidence from norway. International Journal of Child Care and Education Policy, $9(1): 1$.

Spieß, C. K. (2008). Early childhood education and care in Germany: The status quo and reform proposals. Journal of Business Economics, ZfB Special, (1):1-21.

Spieß, C. K. (2013). Investments in education: The early years offer great potential. DIW Economic 
Bulletin, 3(10):3-10.

Stahl, J. F. and Schober, P. S. (2018). Convergence or divergence? educational discrepancies in work-care arrangements of mothers with young children in germany. Work, employment and society, 32(4):629-649.

Statistisches Bundesamt (2017). Kinder und tätige Personen in Tageseinrichtungen und öffentlich geförderter Kindertagespflege, verschiedene Jahre. Statistisches Bundesamt, Wiesbaden.

Van Lancker, W. (2018). Reducing inequality in childcare service use across european countries: What (if any) is the role of social spending? Social Policy \& Administration, 52(1):271-292.

Van Lancker, W. and Ghysels, J. (2012). Who benefits? the social distribution of subsidized childcare in sweden and flanders. Acta Sociologica, 55(2):125-142.

Zachrisson, H. D., Janson, H., and Nærde, A. (2013). Predicting early center care utilization in a context of universal access. Early Childhood Research Quarterly, 28(1):74-82. 


\section{Appendix (for online publication)}

Figure A1: Shortages in day care

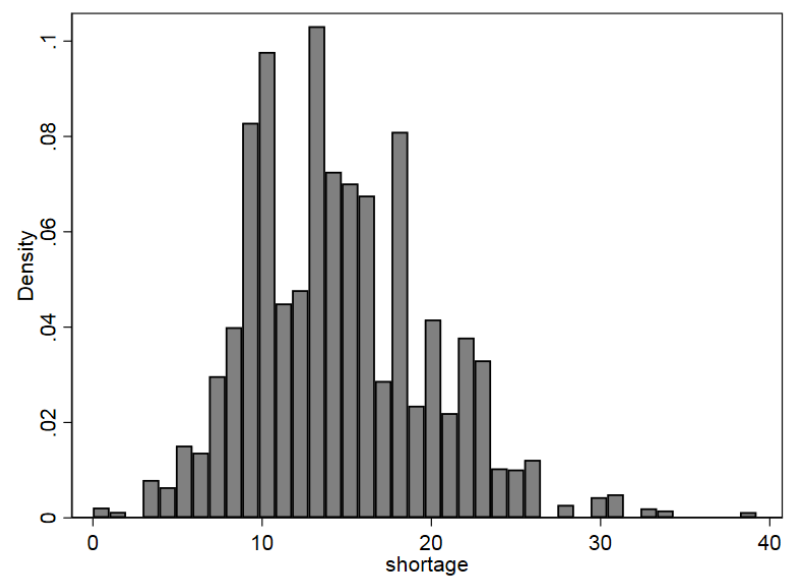

(a) County shortages in percent

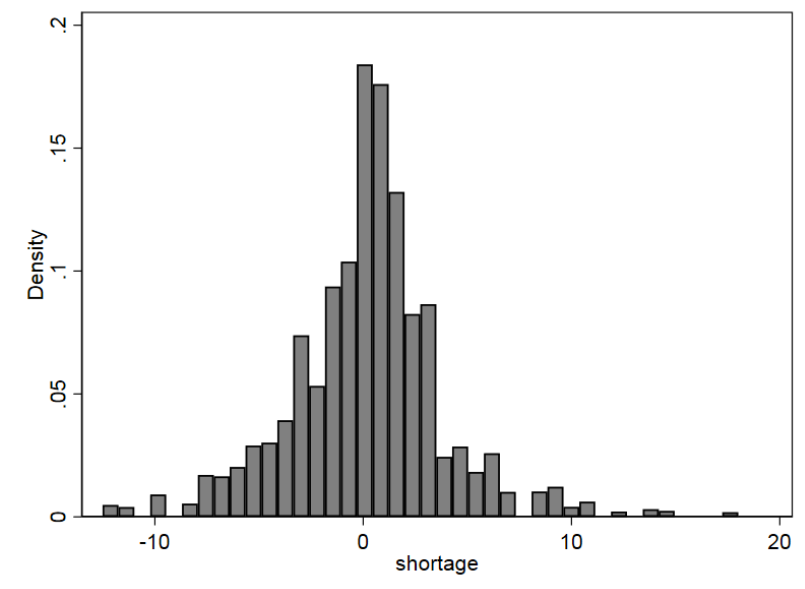

(b) Demeaned county shortages

Notes: Figure shows (a) raw shortages in day care at the county level; and (b) demeaned county shortages subtracting the state-level average. An individual shortage denotes that a day care spot is desired for the child, but the child is not enrolled. Shortages are calculated at the county by year level. The sample is restricted to 50 county by year observations. Panel (b) omits the city-states of Berlin and Hamburg as these are absorbed in our analysis by state and wave fixed effects. 
Figure A2: Day care enrolment and demand by birth country of the parents

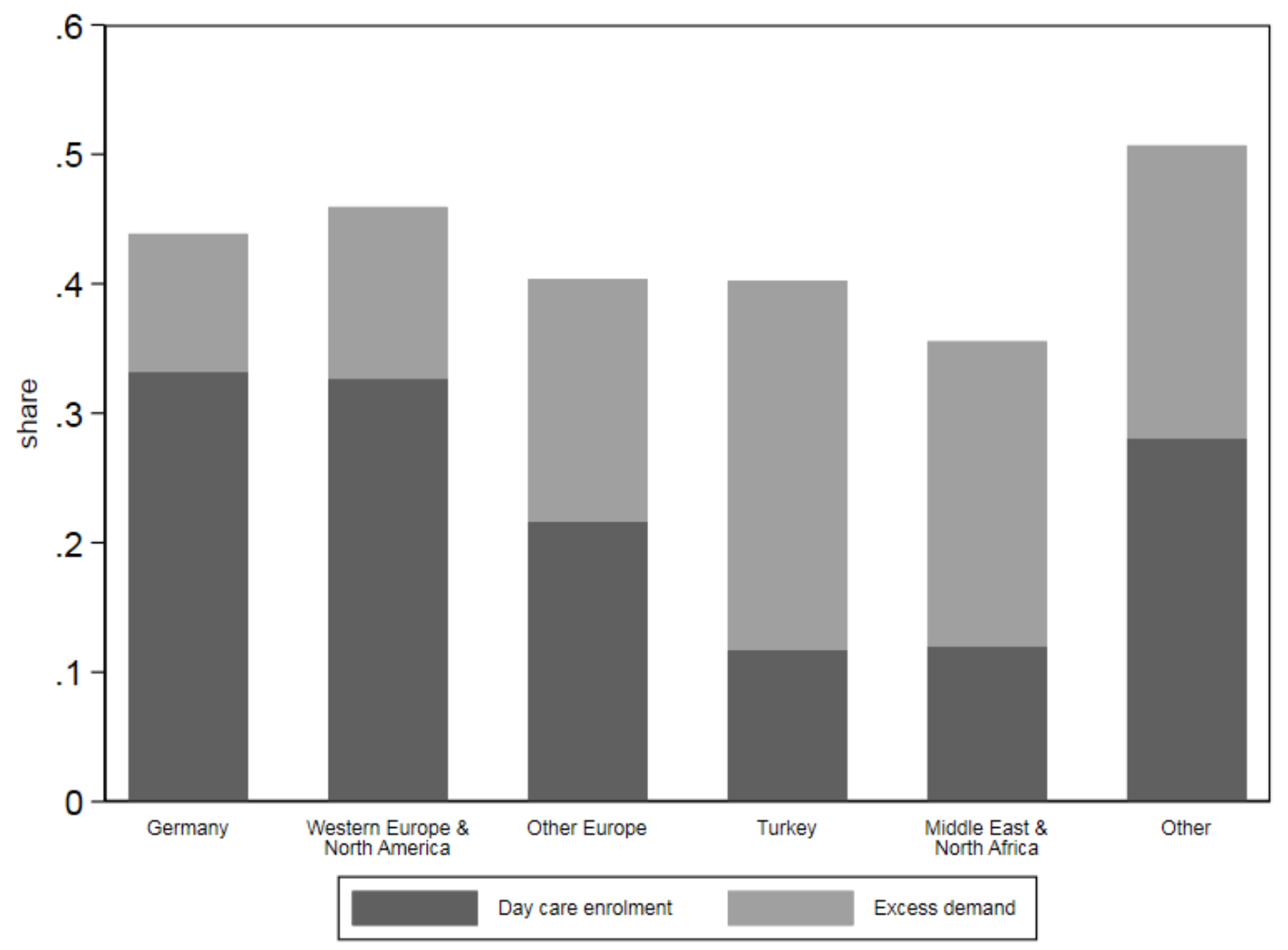

Note: Figure shows day care enrolment and demand by birth country of the responding parent. 
Figure A3: Conditional gaps in day care enrolment and demand

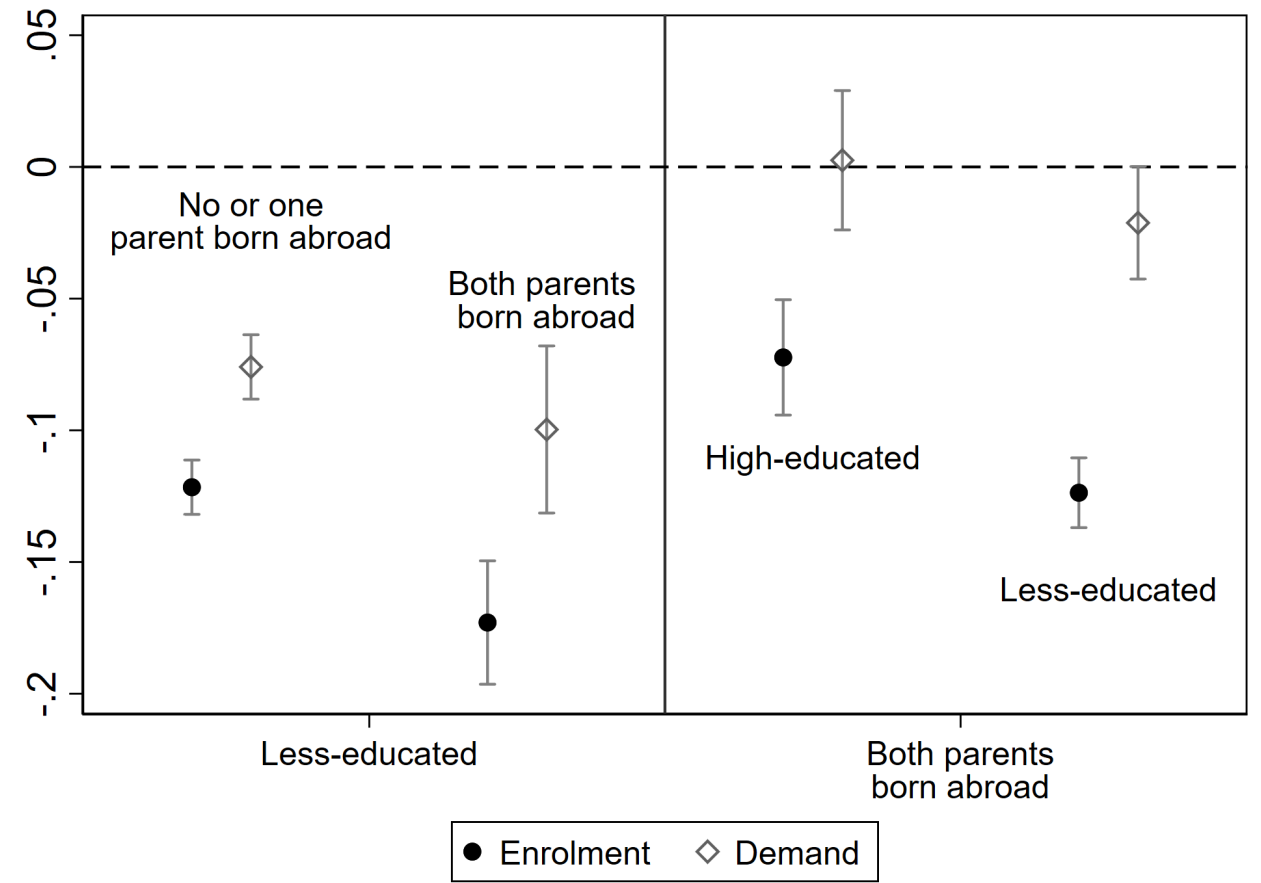

Notes: Figure shows differences in day care enrolment and demand by two measures of family background (education and migration background - defined as having two foreign-born parents), conditional on (not) having a migration background and having high-(or less-) educated parents respectively. Coefficients stem from regressing the dependent variable on the indicator for family background conditional on the factors indicated in separate regressions. Reading example; the day care enrolment gap for children from less-educated parents is $12.2 \mathrm{ppt}$ when no or one parent is born abroad and 17.3 ppt when both parents are born abroad (solid black circles in the left side of the figure). Mean enrolment is 0.31 and mean demand 0.436 . Whiskers indicate $95 \%$ confidence intervals. 
Figure A4: Interaction term of Table 3 by sample restriction

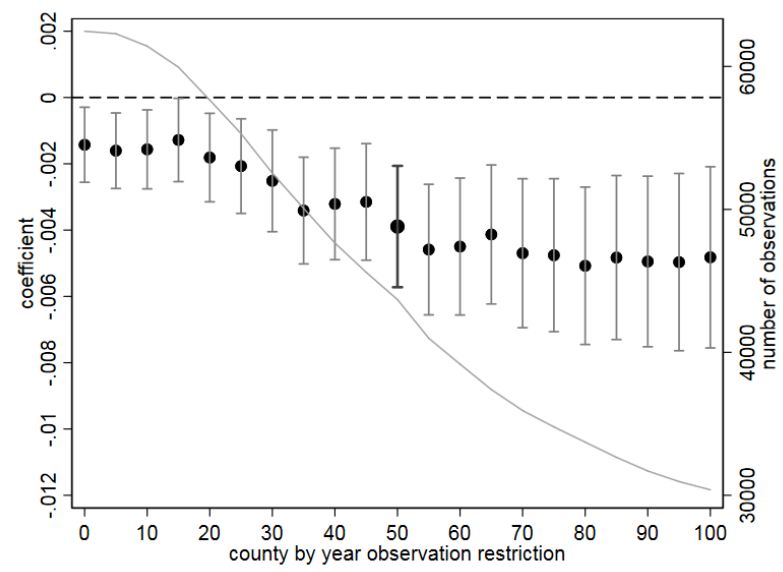

(a) Less-educated parents, col (4)

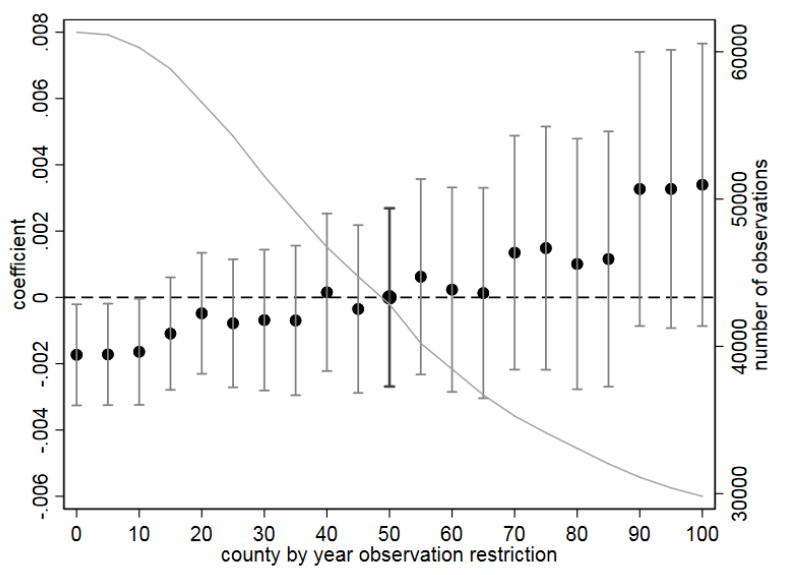

(b) Both parents born abroad, col (8)

Notes: Figures show the coefficient of the interaction term of the county fixed effect model in Table 3 for different county by year number of observation restrictions (in intervals of five). The coefficients are obtained from the specification shown in columns (4) and (8) for less-educated parents and foreign-born parents, respectively. The bold markers indicate the coefficients shown in the table. Whiskers present 95 percent confidence intervals. The grey line and the y-axis on the right show the number of observations used in each estimation. 
Table A1: Share of children below 3 years in child care comparison of KiBS and official statistics

\begin{tabular}{|c|c|c|c|c|c|c|c|c|c|c|}
\hline \multirow[b]{2}{*}{ Federal state } & \multicolumn{2}{|r|}{2012} & \multicolumn{2}{|c|}{2013} & \multicolumn{2}{|r|}{2014} & \multicolumn{2}{|c|}{2015} & \multicolumn{2}{|c|}{2016} \\
\hline & $\begin{array}{c}\mathrm{KiBS} \\
(1)\end{array}$ & $\begin{array}{c}\text { Difference } \\
(2)\end{array}$ & $\begin{array}{c}\mathrm{KiBS} \\
(3)\end{array}$ & $\begin{array}{c}\text { Difference } \\
(4)\end{array}$ & $\begin{array}{c}\text { KiBS } \\
(5)\end{array}$ & $\begin{array}{c}\text { Difference } \\
(6)\end{array}$ & $\begin{array}{c}\mathrm{KiBS} \\
(7)\end{array}$ & $\begin{array}{c}\text { Difference } \\
(8)\end{array}$ & $\begin{array}{c}\mathrm{KiBS} \\
(9)\end{array}$ & $\begin{array}{c}\text { Difference } \\
(10)\end{array}$ \\
\hline Schleswig-Holstein & 0.241 & -0.001 & 0.262 & -0.001 & 0.295 & -0.008 & 0.320 & 0.006 & 0.311 & 0.002 \\
\hline Hamburg & 0.358 & 0.000 & 0.384 & 0.000 & 0.427 & -0.003 & 0.453 & 0.020 & 0.429 & 0.000 \\
\hline Lower Saxony & 0.220 & -0.001 & 0.244 & 0.000 & 0.275 & -0.004 & 0.283 & 0.000 & 0.285 & 0.001 \\
\hline Bremen & 0.212 & 0.000 & 0.232 & 0.000 & 0.264 & -0.005 & 0.281 & 0.010 & 0.271 & 0.001 \\
\hline North Rhein-Westphalia & 0.181 & 0.000 & 0.198 & -0.001 & 0.233 & -0.005 & 0.266 & 0.007 & 0.257 & 0.000 \\
\hline Hesse & 0.236 & -0.001 & 0.256 & -0.001 & 0.283 & -0.005 & 0.306 & 0.009 & 0.297 & 0.000 \\
\hline Rhineland-Palatinate & 0.269 & -0.001 & 0.282 & 0.000 & 0.304 & -0.002 & 0.312 & 0.006 & 0.301 & 0.002 \\
\hline Baden-Württemberg & 0.231 & 0.000 & 0.248 & -0.001 & 0.274 & -0.004 & 0.285 & 0.007 & 0.279 & 0.002 \\
\hline Bavaria & 0.230 & 0.000 & 0.247 & -0.001 & 0.269 & -0.002 & 0.281 & 0.006 & 0.272 & 0.000 \\
\hline Saarland & 0.220 & -0.001 & 0.245 & -0.001 & 0.263 & -0.007 & 0.286 & 0.003 & 0.287 & 0.004 \\
\hline Berlin & 0.425 & -0.001 & 0.436 & -0.001 & 0.459 & -0.001 & 0.475 & 0.016 & 0.459 & 0.000 \\
\hline Brandenburg & 0.534 & 0.000 & 0.536 & 0.000 & 0.572 & -0.006 & 0.579 & 0.011 & 0.572 & 0.000 \\
\hline Mecklenburg-Vorpommern & 0.536 & 0.000 & 0.544 & -0.001 & 0.556 & -0.005 & 0.562 & 0.002 & 0.560 & 0.000 \\
\hline Saxony & 0.464 & 0.000 & 0.472 & 0.000 & 0.494 & -0.005 & 0.511 & 0.005 & 0.507 & 0.001 \\
\hline Saxony-Anhalt & 0.575 & 0.000 & 0.577 & 0.000 & 0.577 & -0.006 & 0.583 & 0.004 & 0.572 & 0.002 \\
\hline Thuringia & 0.497 & -0.001 & 0.513 & -0.001 & 0.519 & -0.005 & 0.527 & 0.003 & 0.524 & 0.002 \\
\hline
\end{tabular}

Notes: Comparison of the share of children below 3 years in day care as calculated with the KiBS data with official statistics provided by the Federal Statistical Office of Germany. 
Table A2: Comparison of analysis sample with dropped observations

\begin{tabular}{|c|c|c|c|}
\hline & $\begin{array}{c}\text { Analysis sample } \\
\text { (1) }\end{array}$ & $\begin{array}{c}\text { Dropped observations } \\
(2)\end{array}$ & $\begin{array}{c}\text { Difference } \\
(3) \\
\end{array}$ \\
\hline \multicolumn{4}{|l|}{ Panel A: individual characteristics } \\
\hline Day care enrolment & $\begin{array}{c}0.374 \\
(0.003)\end{array}$ & $\begin{array}{c}0.243 \\
(0.003)\end{array}$ & $\begin{array}{c}0.131^{* * * *} \\
(0.005)\end{array}$ \\
\hline Day care demanded & $\begin{array}{l}0.490 \\
(0.004)\end{array}$ & $\begin{array}{l}0.380 \\
(0.004)\end{array}$ & $\begin{array}{c}0.110^{* * *} \\
(0.006)\end{array}$ \\
\hline Day care shortage & $\begin{array}{l}0.115 \\
(0.002)\end{array}$ & $\begin{array}{c}0.136 \\
(0.003)\end{array}$ & $\begin{array}{c}-0.021^{* * *} \\
(0.004)\end{array}$ \\
\hline Lower education (no Abitur) & $\begin{array}{l}0.403 \\
(0.004)\end{array}$ & $\begin{array}{l}0.560 \\
(0.005)\end{array}$ & $\begin{array}{c}-0.157^{* * *} * \\
(0.006)\end{array}$ \\
\hline No university degree & $\begin{array}{c}0.493 \\
(0.004)\end{array}$ & $\begin{array}{l}0.660 \\
(0.006)\end{array}$ & $\begin{array}{c}-0.167^{* * * *} \\
(0.007)\end{array}$ \\
\hline German not main language at home & $\begin{array}{c}0.169 \\
(0.003)\end{array}$ & $\begin{array}{c}0.155 \\
(0.004)\end{array}$ & $\begin{array}{c}0.014^{* * * *} \\
(0.005)\end{array}$ \\
\hline Both parents born abroad (\& non-Western) & $\begin{array}{c}0.144 \\
(0.003)\end{array}$ & $\begin{array}{l}0.158 \\
(0.004)\end{array}$ & $\begin{array}{c}-0.014^{* * *} \\
(0.005)\end{array}$ \\
\hline Employed & $\begin{array}{c}0.451 \\
(0.004)\end{array}$ & $\begin{array}{c}0.415 \\
(0.006)\end{array}$ & $\begin{array}{c}0.036^{* * * *} \\
(0.007)\end{array}$ \\
\hline Necessity weighted net equivalent income & $\begin{array}{l}1984.15 \\
(38.715)\end{array}$ & $\begin{array}{l}1729.88 \\
(26.626)\end{array}$ & $\begin{array}{l}254.28^{*} \\
(46.987)\end{array}$ \\
\hline \multicolumn{4}{|l|}{ Panel B: county characteristics } \\
\hline Urban county & $\begin{array}{c}0.671 \\
(0.003)\end{array}$ & $\begin{array}{l}0.216 \\
(0.004)\end{array}$ & $\begin{array}{c}0.455^{* * * *} \\
(0.006)\end{array}$ \\
\hline 1st GDP tercile & $\begin{array}{c}0.042 \\
(0.001)\end{array}$ & $\begin{array}{l}0.276 \\
(0.004)\end{array}$ & $\begin{array}{c}-0.234^{* * * *} \\
(0.004)\end{array}$ \\
\hline 2nd GDP tercile & $\begin{array}{l}0.273 \\
(0.003)\end{array}$ & $\begin{array}{l}0.374 \\
(0.005)\end{array}$ & $\begin{array}{c}-0.101^{* * *} \\
(0.006)\end{array}$ \\
\hline 3rd GDP tercile & $\begin{array}{c}0.685 \\
(0.003)\end{array}$ & $\begin{array}{l}0.350 \\
(0.005)\end{array}$ & $\begin{array}{c}0.335^{* * *} \\
(0.006)\end{array}$ \\
\hline \multicolumn{4}{|l|}{ Panel C: share of federal states } \\
\hline Schleswig-Holstein & $\begin{array}{l}0.046 \\
(0.001)\end{array}$ & $\begin{array}{c}0.019 \\
(0.001)\end{array}$ & $\begin{array}{c}0.027^{* * *} \\
(0.001)\end{array}$ \\
\hline Hamburg & $\begin{array}{l}0.049 \\
(0.001)\end{array}$ & - & - \\
\hline Lower Saxony & $\begin{array}{c}0.083 \\
(0.002)\end{array}$ & $\begin{array}{c}0.103 \\
(0.002)\end{array}$ & $\begin{array}{c}-0.019^{* * *} \\
(0.003)\end{array}$ \\
\hline Bremen & $\begin{array}{l}0.016 \\
(0.000)\end{array}$ & - & - \\
\hline North Rhein-Westphalia & $\begin{array}{l}0.051 \\
(0.003)\end{array}$ & $\begin{array}{c}0.389 \\
(0.005)\end{array}$ & $\begin{array}{c}-0.338^{* * *} \\
(0.006)\end{array}$ \\
\hline Hesse & $\begin{array}{l}0.078 \\
(0.002)\end{array}$ & $\begin{array}{l}0.076 \\
(0.002)\end{array}$ & $\begin{array}{c}0.002 \\
(0.003)\end{array}$ \\
\hline Rhineland-Palatinate & $\begin{array}{l}0.063 \\
(0.001)\end{array}$ & $\begin{array}{l}0.031 \\
(0.001)\end{array}$ & $\begin{array}{c}0.033^{* * * *} \\
(0.002)\end{array}$ \\
\hline Baden-Württemberg & $\begin{array}{l}0.104 \\
(0.003)\end{array}$ & $\begin{array}{l}0.166 \\
(0.004)\end{array}$ & $\begin{array}{c}-0.062^{* * *} \\
(0.004)\end{array}$ \\
\hline Bavaria & $\begin{array}{c}0.177 \\
(0.003)\end{array}$ & $\begin{array}{c}0.140 \\
(0.003)\end{array}$ & $\begin{array}{c}0.037^{* * * *} \\
(0.005)\end{array}$ \\
\hline Saarland & $\begin{array}{l}0.020 \\
(0.000)\end{array}$ & $\begin{array}{c}0.001 \\
(0.000)\end{array}$ & $\begin{array}{c}0.019^{* * * *} \\
(0.000)\end{array}$ \\
\hline Berlin & $\begin{array}{c}0.097 \\
(0.002)\end{array}$ & - & - \\
\hline Brandenburg & $\begin{array}{c}0.037 \\
(0.001)\end{array}$ & $\begin{array}{c}0.019 \\
(0.001)\end{array}$ & $\begin{array}{c}0.019^{* * *} \\
(0.001)\end{array}$ \\
\hline Mecklenburg-Vorpommern & $\begin{array}{c}0.033 \\
(0.001)\end{array}$ & $\begin{array}{c}0.004 \\
(0.000)\end{array}$ & $\begin{array}{c}0.029^{* * *} \\
(0.001)\end{array}$ \\
\hline Saxony & $\begin{array}{c}0.077 \\
(0.001)\end{array}$ & $\begin{array}{c}0.024 \\
(0.001)\end{array}$ & $\begin{array}{c}0.053^{* * *} \\
(0.002)\end{array}$ \\
\hline Saxony-Anhalt & $\begin{array}{c}0.033 \\
(0.001)\end{array}$ & $\begin{array}{c}0.017 \\
(0.001)\end{array}$ & $\begin{array}{c}0.016^{* * * *} \\
(0.001)\end{array}$ \\
\hline Thuringia & $\begin{array}{c}0.036 \\
(0.001)\end{array}$ & $\begin{array}{c}0.014 \\
(0.000)\end{array}$ & $\begin{array}{c}0.022^{* * *} \\
(0.001)\end{array}$ \\
\hline Observations & 43,691 & 18,782 & 62,473 \\
\hline
\end{tabular}

Notes: Comparing characteristics of observations used in the analysis sample and observations dropped due to the sample restriction of having at least 50 observations per county and year. Panel A shows individual characteristics, Panel B displays the share of observations coming from each federal statg. $6^{* * * * * *} p<0.01,{ }^{* *} p<0.05,{ }^{*} p<0.1$. 
Appendix Table A2 compares the analysis sample with the dropped observations. The sampling design favours observations coming from counties with a larger population (especially urban counties) and those from federal states with a smaller population as these have fewer counties and every state has roughly the same number of unweighted observations per year. The analysis sample is positively selected; day care enrolment, income, and employment rates are higher, the share with foreign-born parents and less-educated parents levels is smaller (all differences are significant at the 1 percent level). Although the sample restriction means that our sample is not fully representative for Germany, the data used still covers a large fraction of the German population and advances on previous studies looking at specific groups or smaller regions. 
Table A3: Characteristics by country of origin

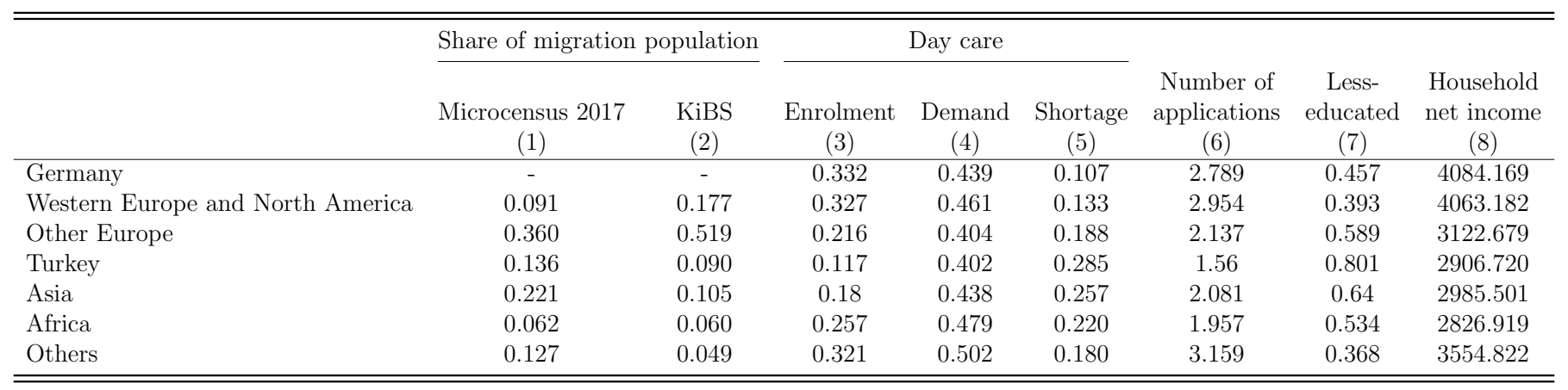

Notes: Table shows characteristics of children with different migration backgrounds. Shares of the Microcensus data refer to children aged 0-5, KiBS data 0-3. For Western Europe and North America, and Other Europe the composition between Microcensus and KiBS data differs slightly as the Microcensus data only contains the number of children from EU28 and the 12 countries with the largest migrant population share of those. Western European countries not listed are thus assigned to Other Europe, leading to an underestimation of the Western Europe share in the Microcensus. When countries are assigned to EU28 and residual European countries the share in the Microcensus are 0.291 and 0.286 , and 0.344 and 0.386 in the KiBS respectively. In the KiBS data, the country refers to birth country of the responding parent. Microcensus data obtained from the Federal Statistical Office. 
Table A4: Day care enrolment, family background and regional shortages alternative family background definition

\begin{tabular}{|c|c|c|c|c|c|c|c|c|}
\hline \multirow[b]{2}{*}{ Mean of dep. var } & \multicolumn{8}{|c|}{ Day care enrolment } \\
\hline & $\begin{array}{c}(1) \\
0.379\end{array}$ & $\begin{array}{c}(2) \\
0.379\end{array}$ & $\begin{array}{c}(3) \\
0.379\end{array}$ & $\begin{array}{c}(4) \\
0.379\end{array}$ & $\begin{array}{c}(5) \\
0.375\end{array}$ & $\begin{array}{c}(6) \\
0.375\end{array}$ & $\begin{array}{c}(7) \\
0.375\end{array}$ & $\begin{array}{c}(8) \\
0.375\end{array}$ \\
\hline No university & $\begin{array}{c}-0.095^{* * *} \\
(0.028)\end{array}$ & $\begin{array}{l}-0.031 \\
(0.032)\end{array}$ & $\begin{array}{c}-0.086^{* * *} \\
(0.028)\end{array}$ & $\begin{array}{l}-0.031 \\
(0.032)\end{array}$ & & & & \\
\hline No university $\times$ shortage & & $\begin{array}{c}-0.004^{* * *} \\
(0.001)\end{array}$ & & $\begin{array}{c}-0.004^{* * *} \\
(0.001)\end{array}$ & & & & \\
\hline Migration background & & & & & $\begin{array}{c}-0.139 * * * \\
(0.042)\end{array}$ & $\begin{array}{c}-0.136^{* * *} \\
(0.049)\end{array}$ & $\begin{array}{c}-0.127^{* * *} \\
(0.043)\end{array}$ & $\begin{array}{c}-0.126^{* *} \\
(0.050)\end{array}$ \\
\hline Migration $\times$ shortage & & & & & & $\begin{array}{l}-0.000 \\
(0.001)\end{array}$ & & $\begin{array}{l}-0.000 \\
(0.001)\end{array}$ \\
\hline Shortage & $\begin{array}{c}-0.004^{* * *} \\
(0.001)\end{array}$ & $\begin{array}{l}-0.002 \\
(0.001)\end{array}$ & $\begin{array}{c}-0.004^{* * *} \\
(0.001)\end{array}$ & $\begin{array}{l}-0.002 \\
(0.001)\end{array}$ & $\begin{array}{c}-0.005^{* * *} \\
(0.001)\end{array}$ & $\begin{array}{c}-0.005^{* * *} \\
(0.001)\end{array}$ & $\begin{array}{c}-0.004^{* * *} \\
(0.001)\end{array}$ & $\begin{array}{c}-0.004^{* * *} \\
(0.001)\end{array}$ \\
\hline State $\times$ wave FEs & $\mathrm{Y}$ & $\mathrm{Y}$ & & & $\mathrm{Y}$ & $\mathrm{Y}$ & & \\
\hline County FEs & & & $\mathrm{Y}$ & $\mathrm{Y}$ & & & $\mathrm{Y}$ & $\mathrm{Y}$ \\
\hline Wave FEs & & & $\mathrm{Y}$ & $\mathrm{Y}$ & & & $\mathrm{Y}$ & $\mathrm{Y}$ \\
\hline Observations & 35,603 & 35,603 & 35,603 & 35,603 & 43,536 & 43,536 & 43,536 & 43,536 \\
\hline
\end{tabular}

Notes: The sample is restricted to leave-one-out shortages calculated from at least 50 observations per county. Migration background indicates that German is not the main language at home. All estimates control for the sex and age of the child, marital status of the respondent and an indicator for urban counties, the county fixed effects estimates include regional controls at the state by year level (unemployment, population density, GDP per capita and migration share). Standard errors, clustered at the individual level, in parentheses. *** $p<0.01,{ }^{* *} p<0.05,{ }^{*} p<0.1$. 
Table A5: Day care enrolment, family background and regional shortages - leave-one-out shortage

\begin{tabular}{|c|c|c|c|c|c|c|c|c|}
\hline \multirow[b]{2}{*}{ Mean of dep. var } & \multicolumn{8}{|c|}{ Day care enrolment } \\
\hline & $\begin{array}{c}(1) \\
0.375\end{array}$ & $\begin{array}{c}(2) \\
0.375 \\
\end{array}$ & $\begin{array}{c}(3) \\
0.375 \\
\end{array}$ & $\begin{array}{c}(4) \\
0.375\end{array}$ & $\begin{array}{c}(5) \\
0.376\end{array}$ & $\begin{array}{c}(6) \\
0.376 \\
\end{array}$ & $\begin{array}{c}(7) \\
0.376\end{array}$ & $\begin{array}{c}(8) \\
0.376\end{array}$ \\
\hline Less educated & $\begin{array}{c}-0.105^{* * *} \\
(0.021)\end{array}$ & $\begin{array}{l}-0.035 \\
(0.025)\end{array}$ & $\begin{array}{c}-0.097^{* * *} * \\
(0.021)\end{array}$ & $\begin{array}{c}-0.041 \\
(0.025)\end{array}$ & & & & \\
\hline Less educated $\times$ shortage $_{-i}$ & & $\begin{array}{c}-0.005^{* * *} \\
(0.001)\end{array}$ & & $\begin{array}{c}-0.004^{* * *} \\
(0.001)\end{array}$ & & & & \\
\hline Migration background & & & & & $\begin{array}{c}-0.097^{* *} \\
(0.043)\end{array}$ & $\begin{array}{c}-0.099 * * \\
(0.050)\end{array}$ & $\begin{array}{c}-0.090^{* *} \\
(0.045)\end{array}$ & $\begin{array}{c}-0.099^{*} \\
(0.051)\end{array}$ \\
\hline Migration $\times$ shortage $_{-i}$ & & & & & & $\begin{array}{c}0.000 \\
(0.001)\end{array}$ & & $\begin{array}{c}0.001 \\
(0.001)\end{array}$ \\
\hline Shortage $_{-i}$ & $\begin{array}{c}-0.001^{*} \\
(0.001)\end{array}$ & $\begin{array}{c}0.001 \\
(0.001) \\
\end{array}$ & $\begin{array}{c}0.003^{* * *} \\
(0.001)\end{array}$ & $\begin{array}{c}0.005^{* * *} \\
(0.001)\end{array}$ & $\begin{array}{c}-0.001^{*} \\
(0.001)\end{array}$ & $\begin{array}{c}-0.001^{*} \\
(0.001)\end{array}$ & $\begin{array}{c}0.003^{* * *} \\
(0.001)\end{array}$ & $\begin{array}{c}0.003^{* * *} \\
(0.001)\end{array}$ \\
\hline State $\times$ wave FEs & $\mathrm{Y}$ & $\mathrm{Y}$ & & & $\mathrm{Y}$ & $\mathrm{Y}$ & & \\
\hline County FEs & & & $\mathrm{Y}$ & $\mathrm{Y}$ & & & $\mathrm{Y}$ & $\mathrm{Y}$ \\
\hline Wave FEs & & & $\mathrm{Y}$ & $\mathrm{Y}$ & & & $\mathrm{Y}$ & $\mathrm{Y}$ \\
\hline Observations & 43,668 & 43,668 & 43,668 & 43,668 & 42,845 & 42,845 & 42,845 & 42,845 \\
\hline
\end{tabular}

Notes: In contrast to Table 3, this table uses leave-one-out county shortages, i.e. excluding the individual contribution. County-level correlates based on equations (1) and (2). Migration background indicates that both parents are born abroad and non-Western. The sample is restricted to a minimum of 50 observations per county. All estimates control for the sex and age of the child, marital status of the respondent and an indicator for urban counties. The county fixed effects estimates include regional controls at the state by year level (unemployment, population density, GDP per capita and migration share). Standard errors, clustered at the individual level, in parentheses. ${ }^{* * *} p<0.01,{ }^{* *} p<0.05,{ }^{*} p<0.1$. 
Table A6: Day care enrolment, family background and regional shortages

\begin{tabular}{lcccc}
\hline \hline & \multicolumn{4}{c}{ Day care enrolment } \\
\cline { 2 - 5 } Mean of dep. var & $(1)$ & $(2)$ & $(3)$ & $(4)$ \\
& 0.378 & 0.378 & 0.391 & 0.391 \\
\hline \multirow{2}{*}{ Below median pre-birth income } & $-0.149^{* * *}$ & -0.096 & & \\
Low income $\times$ shortage & $(0.057)$ & $(0.070)$ & & \\
Welfare recipient & & -0.003 & & \\
Welfare $\times$ shortage & & & $-0.190^{* * *}$ & $-0.227^{* * *}$ \\
& & & $(0.065)$ & $(0.075)$ \\
Shortage & & & & 0.002 \\
& $-0.004^{* *}$ & -0.002 & $-0.006^{* * *}$ & $-0.0006^{* * *}$ \\
\hline State $\times$ wave FEs & $(0.002)$ & $(0.002)$ & $(0.001)$ & $(0.001)$ \\
\hline Observations & $\mathrm{Y}$ & $\mathrm{Y}$ & $\mathrm{Y}$ & $\mathrm{Y}$ \\
\hline \hline
\end{tabular}

Notes: County level correlates based on equation (1) and (2). The sample is restricted to a minimum of 50 observations per county. All estimates control for the sex and age of the child, marital status of the respondent. Information on pre-birth income and welfare recipient status available in wave 4 , and wave 4 and 5 respectively. Standard errors, clustered at the individual level, in parentheses. ${ }^{* * *} p<0.01,{ }^{* *} p<0.05,{ }^{*} p<0.1$. 
Table A7: Day care enrolment, family background and fees

\begin{tabular}{lcccc}
\hline \hline & \multicolumn{4}{c}{ Day care enrolment } \\
\cline { 2 - 5 } Mean of dep. var & $(1)$ & $(2)$ & $(3)$ & $(4)$ \\
& 0.378 & 0.378 & 0.377 & 0.377 \\
Less-educated & $-0.182^{* * *}$ & -0.050 & & \\
Less-educated $\times$ fees & $(0.053)$ & $(0.072)$ & & \\
Migration background & & $-0.057^{* * *}$ & & 0.043 \\
Migration $\times$ fees & $(0.021)$ & & 0.022 & $(0.101)$ \\
& & & $(0.076)$ & -0.009 \\
Day care fees & \multicolumn{4}{c}{$0.028)$} \\
& $0.036^{* * *}$ & $0.058^{* * *}$ & $0.052^{* * *}$ & $0.053^{* * *}$ \\
\hline State FEs & $(0.013)$ & $(0.015)$ & $(0.012)$ & $(0.014)$ \\
\hline Observations & $\mathrm{Y}$ & $\mathrm{Y}$ & $\mathrm{Y}$ & $\mathrm{Y}$ \\
\hline \hline
\end{tabular}

Notes: County level correlates based on equation (1). The sample is restricted to a minimum of 50 observations per county. All estimates control for the sex and age of the child, marital status of the respondent and indicators for urban counties and terciles for the GDP per capita of the counties. As fees are only available for those in day care, we use our data set to impute hypothetical fees for all children. For this we regress observed day care fees on a number of variables that commonly determine day care fees (number of children in household, 15 household net income bins, age dummies for the children, desired hours corrected by the median gap between desired and actually used hours for those enrolled in day care, and a binary indicator for welfare recipient). Regressions are run by state and include county fixed effects to allow for regional variation in fee structure. In a second step, we predict hypothetical fees for each child based on the coefficients obtained above and then compute the county average. Standard errors, clustered at the individual level, in parentheses. ${ }^{* * *} p<0.01,{ }^{* *} p<0.05$, $* p<0.1$. 
CENTRE FOR ECONOMIC PERFORMANCE

Recent Discussion Papers

\begin{tabular}{|c|c|c|}
\hline 1649 & $\begin{array}{l}\text { S. Federico } \\
\text { F. Hassan } \\
\text { V. Rappoport }\end{array}$ & Trade Shocks and Credit Reallocation \\
\hline 1648 & Max Nathan & $\begin{array}{l}\text { Does Light Touch Cluster Policy Work? } \\
\text { Evaluating the Tech City Programme }\end{array}$ \\
\hline 1647 & $\begin{array}{l}\text { Stuart Campbell } \\
\text { Lindsey Macmillan } \\
\text { Richard Murphy } \\
\text { Gill Wyness }\end{array}$ & $\begin{array}{l}\text { Inequalities in Student to Course Match: } \\
\text { Evidence from Linked Administrative Data }\end{array}$ \\
\hline 1646 & Cong Peng & $\begin{array}{l}\text { Does E-Commerce Reduce Traffic } \\
\text { Congestion? Evidence from Alibaba Single } \\
\text { Day Shopping Event }\end{array}$ \\
\hline 1645 & $\begin{array}{l}\text { Dan Andrews } \\
\text { Chiara Criscuolo } \\
\text { Peter N. Gal }\end{array}$ & $\begin{array}{l}\text { The Best versus the Rest: Divergence across } \\
\text { Firms during the Global Productivity } \\
\text { Slowdown }\end{array}$ \\
\hline 1644 & $\begin{array}{l}\text { Christopher Cornwell } \\
\text { Ian M. Schmutte } \\
\text { Daniela Scur }\end{array}$ & $\begin{array}{l}\text { Building a Productive Workforce: The Role of } \\
\text { Structured Management Practices }\end{array}$ \\
\hline 1643 & $\begin{array}{l}\text { Paul Dolan } \\
\text { Georgios Kavetsos } \\
\text { Christian Krekel } \\
\text { Dimitris Mavridis } \\
\text { Robert Metcalfe } \\
\text { Claudia Senik } \\
\text { Stefan Szymanski } \\
\text { Nicolas R. Ziebarth }\end{array}$ & $\begin{array}{l}\text { Quantifying the Intangible Impact of the } \\
\text { Olympics Using Subjective Well-Being Data }\end{array}$ \\
\hline 1642 & $\begin{array}{l}\text { Xavier Jaravel } \\
\text { Erick Sager }\end{array}$ & $\begin{array}{l}\text { What are the Price Effects of Trade? Evidence } \\
\text { from the US and Implications for Quantitative } \\
\text { Trade Models }\end{array}$ \\
\hline 1641 & $\begin{array}{l}\text { Johannes Boehm } \\
\text { Jan Sonntag }\end{array}$ & $\begin{array}{l}\text { Vertical Integration and Foreclosure: } \\
\text { Evidence from Production Network Data }\end{array}$ \\
\hline
\end{tabular}




\begin{tabular}{|c|c|c|}
\hline 1640 & $\begin{array}{l}\text { Teodora Borota } \\
\text { Fabrice Defever } \\
\text { Giammario Impullitti }\end{array}$ & $\begin{array}{l}\text { Innovation Union: Costs and Benefits of } \\
\text { Innovation Policy Coordination }\end{array}$ \\
\hline 1639 & $\begin{array}{l}\text { Monica Langella } \\
\text { Alan Manning }\end{array}$ & $\begin{array}{l}\text { Residential Mobility and Unemployment in } \\
\text { the UK }\end{array}$ \\
\hline 1638 & $\begin{array}{l}\text { Christos Genakos } \\
\text { Mario Pagliero }\end{array}$ & $\begin{array}{l}\text { Competition and Pass-Through: Evidence } \\
\text { from Isolated Markets }\end{array}$ \\
\hline 1637 & $\begin{array}{l}\text { Holger Breinlich } \\
\text { Elsa Leromain } \\
\text { Dennis Novy } \\
\text { Thomas Sampson }\end{array}$ & $\begin{array}{l}\text { Voting With Their Money: Brexit and } \\
\text { Outward Investment by UK Firms }\end{array}$ \\
\hline 1636 & Maria Sanchez-Vidal & Retail Shocks and City Structure \\
\hline 1635 & $\begin{array}{l}\text { Felipe Carozzi } \\
\text { Sefi Roth }\end{array}$ & $\begin{array}{l}\text { Dirty Density: Air Quality and the Density of } \\
\text { American Cities }\end{array}$ \\
\hline 1634 & $\begin{array}{l}\text { Nicholas Bloom } \\
\text { John Van Reenen } \\
\text { Heidi Williams }\end{array}$ & A Toolkit of Policies to Promote Innovation \\
\hline 1633 & $\begin{array}{l}\text { Stephan E. Maurer } \\
\text { Ferdinand Rauch }\end{array}$ & $\begin{array}{l}\text { Economic Geography Aspects of the Panama } \\
\text { Canal }\end{array}$ \\
\hline 1632 & Nikhil Datta & $\begin{array}{l}\text { Willing to Pay for Security: A Discrete } \\
\text { Choice Experiment to Analyse Labour Supply } \\
\text { Preferences }\end{array}$ \\
\hline 1631 & $\begin{array}{l}\text { Gabriel M. Ahlfeldt } \\
\text { Volker Nitsch } \\
\text { Nicolai Wendland }\end{array}$ & $\begin{array}{l}\text { Ease Versus Noise: Long-Run Changes in the } \\
\text { Value of Transport (Dis)amenities }\end{array}$ \\
\hline & & \\
\hline
\end{tabular}

The Centre for Economic Performance Publications Unit

Tel: +44 (0)207955 7673 Email info@ cep.lse.ac.uk

Website: http://cep.lse.ac.uk Twitter: @CEP_LSE 